\title{
Fireside tales: understanding experiences of previous eruptions among other factors that influence the decision to evacuate from eruptive activity of Volcán de Fuego.
}

\author{
Ailsa K. Naismith ${ }^{\star \alpha}$, M. Teresa Armijos $\beta$, Edgar Antonio Barrios Escobar $\gamma$, \\ William Chigna $^{\delta}$, I. Matthew Watson ${ }^{\alpha}$ \\ ${ }^{\alpha}$ School of Earth Sciences, Wills Memorial Building, University Bristol, Queens Road, Bristol, BS8 1RJ, UK. \\ $\beta$ School of International Development, University of East Anglia, Norwich, Norfolk, NR4 7TJ, UK.

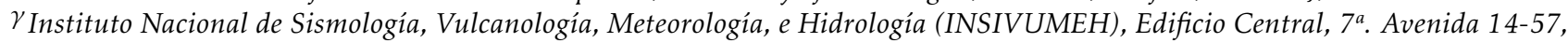 \\ Zona 13, Ciudad de Guatemala, Guatemala. \\ ${ }^{\delta}$ Coordinadora Nacional para la Reducción de Desastres (CONRED), Avenida Hincapié 21-72, Zona 13, Ciudad de Guatemala,
} Guatemala.

\begin{abstract}
Volcán de Fuego (Guatemala) is an active stratovolcano capable of large (VEI $\sim 2$ ) explosive eruptions like that of $3^{\text {rd }}$ June 2018, which triggered pyroclastic flows that devastated the community of San Miguel Los Lotes and caused hundreds of fatalities and severe long-term socio-economic impacts. Future volcanic risk mitigation efforts are likely to involve temporary evacuation of local communities, the success of which requires co-operation between locals, scientists, and decision-makers. However, locals' experiences of eruptive activity, and how these experiences influence their responses to evacuation, have not been studied in detail. In 2019 we conducted an investigation of these themes through qualitative research methods involving semi-structured interviews that focussed on direct experience as opposed to volcanic risk perception. We found substantial differences between scientists' and locals' observations of Fuego's activity. Furthermore, a clear disparity emerged between communities on Fuego's west and east flanks in terms of direct prior experience of eruptions and communication with authorities. These findings have serious implications for future evacuation efforts at Fuego and at other highly populated active volcanoes.
\end{abstract}

\section{RESUMEN}

El Volcán de Fuego (Guatemala) es capaz de erupciones catastróficas como la del 3 de junio de 2018, cuando flujos piroclásticos destruyeron la comunidad de San Miguel Los Lotes y causaron numerosos muertos e impactos socioeconomicos severos en el largo plazo. Al futuro, la mitigación del riesgo volcánico implicará la evacuación de las comunidades locales, cuyo éxito requiere la cooperación entre autoridades y la población. Sin embargo, se sabe poco sobre cuales son las experiencias de actividad eruptiva de estos grupos, y cómo estas experiencias afectan sus respuestas a la evacuación. En 2019 realizamos una investigación de estos temas y encontramos diferencias significativas entre las observaciones científicas y de la población de la actividad de Fuego. Además, surgió una disparidad entre las comunidades en diferentes flancos del volcán en términos de la experiencia vivida de las erupciones anteriores y de la comunicación con autoridades. Estos resultados tienen implicaciones para los futuros esfuerzos de evacuación en Fuego y en volcanes análogos.

Keywords: Pyroclastic flows; Self-evacuation; Trust; Knowledge; Risk; Volcán de Fuego

\section{InTRODUCTION}

On $3^{\text {rd }}$ June 2018, an explosive paroxysmal eruption of Volcán de Fuego ("Chi'gag" in Kaqchikel Maya), an active stratovolcano in southern Guatemala, generated a series of pyroclastic flows that descended Barranca Las Lajas and buried the community of San Miguel Los Lotes. 332 people have been reported as offi-

${ }^{*}$ Corresponding author: ailsanaismith@gmail.com cially missing, although independent estimates suggest that up to 2,900 people were killed [Associated Press 2018]. In addition, an estimated 5,000 people lost their homes [Noticias ONU 2018]. Scientists informed on activity continuously from 06:30 a.m., while authorities persistently tried to remove people from high-risk areas. However, national media later highlighted the disconnect between these authorities supposedly fulfilling their responsibilities and the high death toll. In partic- 
ular, media focussed on the different fates of geographically close communities: why did the private golf resort of La Reunión successfully evacuate, yet Los Lotes, two kilometres further south, suffer such extensive human loss [Tobar 2018]?. This question relates to the larger issue of the ability and willingness of communities to evacuate from eruptive crisis. By investigating the different ways in which people experience Fuego's eruptive activity, and the factors that influence evacuation, this paper provides possible explanations and future actions to prevent these situations from happening again. It highlights the importance of understanding local residents' priorities, interests and decisionmaking processes when managing volcanic risk.

Pyroclastic flows are frequently produced by eruptive activity of Volcán de Fuego [Naismith et al. 2019]. However, the estimated 15.1 million cubic meters of pyroclastic flow material deposited in Las Lajas on $3^{\text {rd }}$ June [Albino et al. 2020] was exceptionally large for a single eruption. It was more than double the average volume of pyroclastic flows registered since 1999 [Ferres and Escobar-Wolf 2018]. Nevertheless, eruptions producing smaller pyroclastic flow volumes have repeatedly triggered evacuation (e.g. September 2012, May 2017, November 2018). The high velocity of pyroclastic flows means that evacuation is the only procedure that effectively prevents loss of life. However, prior evacuation is a complex and costly procedure that involves significant resources from national authorities. The additional social and economic pressures affecting members of communities like Los Lotes suggests that their compliance with evacuation may be even more difficult. Yet, as this paper reports, authorities believe that locals have the capacity and responsibility to recognize changes in volcanic activity and to self-evacuate when volcanic risk becomes intolerable. It is precisely this difference in opinion that continues to generate risk for the people living near Volcán de Fuego. This paper argues that understanding differences in experiences of previous eruptions and in volcanic risk tolerance between locals and authorities is critical to effective volcanic risk mitigation (including evacuation). It does so through an exploration of the diverse coping strategies and important factors that influence peoples' decisionmaking in the face of volcanic crisis.

This paper presents findings from studies conducted in 2018 and 2019 that explicitly compare (1) how local people experience recent activity of Fuego; (2) how members of Guatemalan authorities, INSIVUMEH (Instituto Nacional de Sismología, Vulcanología, Meteorología e Hidrología) and CONRED (Coordinadora Nacional para la Reducción de Desastres), experience the same and; (3) the potential implications of these differences for volcanic risk and its mitigation at Fuego. We deliberately chose to study direct experience of eruptive activity as opposed to volcanic risk perception. The term "volcanic risk perception" implicitly assumes that volcanic risk is the only risk that local residents of a volcano encounter. Our findings show that although authorities' experiences of Fuego's activity are similar to changes seen in remote sensing data, locals see the same events in an entirely different way. Local residents are highly aware of Fuego's activity and knowledgeable of most volcanic hazards. However, since Fuego's reactivation in 1999, the only eruptions they clearly remember and identify are those that required a communitywide response which interrupted day-to-day life. This paper finds that the root causes of risk identified at other volcanoes (e.g. security concerns, maintaining livelihoods) are also present at Fuego. This paper also shows that a component of volcanic risk particular to Fuego is the disparity between communities on its west and east flanks in terms of direct experience of previous eruptions and communication with INSIVUMEH and CONRED. Through reference to volcanic risk perception and evacuation literature, this paper confirms that direct experience of eruptions is only one of many factors informing response to eruptive crisis at Fuego. For local residents, many competing factors (including existing socio-economic pressures and specific impacts associated with evacuation) create conditions that impede evacuation. At Fuego, the current policy places the majority of the responsibility for evacuation on locals, ignoring the implications of these competing factors. We argue that both the great variability in experiences of eruptive activity (both between authorities and locals, and between locals in different communities) and the social pressures affecting locals have implications for volcanic risk at Fuego. These act parallel and sometimes in opposition to any potential increase in local risk awareness and may have severe consequences for the success of future evacuations.

\section{BACKgROUND}

\subsection{Developments in volcanic risk literature}

Gilbert White's 1942 work on flood hazard in the US is an early study of human response to natural hazards. White [1942] argued that response is formed of adjustment to one's environment and implementing practices to minimize loss. In the 1970s, concern that researchers were focussed on extreme natural events at the expense of root social causes of risk [e.g. Hewitt 1983] drove studies that focussed on vulnerability, or the existing socio-economic conditions that render an individual susceptible to disaster [Blaikie et al. 2014]. Loss of livelihood was identified as a key facet of vulnerability, both in more economically developed countries [e.g. Dibben 1999] and less developed [e.g. Lane et al. 2003]. At Volcán Tungurahua in Ecuador, efforts to create livelihood alternatives outside areas of high volcanic risk have evolved with adaptive forms of risk management. Here, local residents benefit from the greater security of such alternative livelihoods and 
take collective decisions to temporarily evacuate, thus minimizing the disruptive effects of forced evacuation [Armijos and Few 2015]. Local residents in other countries have also engaged with temporary evacuation, for instance at Mt Merapi, Indonesia [Andreastuti et al. 2019]. This demonstrates that physical and social drivers of volcanic risk are not of equal priority in local peoples' response to volcanic activity, as local people respond to socio-economic pressures before adjusting to hazards [Dibben 2008; Gaillard 2008]. From the perspective of some volcanologists and disaster risk officials, however, locals consistently appear to underestimate volcanic risk [Donovan et al. 2014]. Apparent underestimation of risk has been observed in communities near Katla, Iceland [Jóhannesdóttir and Gísladóttir 2010], and Ruapehu, New Zealand [Johnston et al. 1999]. This paper contributes to the debate by simultaneously presenting perspectives of locals, volcanologists, and officials in a single environment.

The view that locals underestimate volcanic risk can lead to the mistaken belief that locals are deficient in knowledge or have miscalculated their priorities. Communities affected by natural hazards often develop "coping cultures" to adapt to their environment [e.g. Bankoff 2007]. Conversely, academic knowledge of risk is not authoritative, although this group is often credited with an 'accurate perception' of the risk [Christie et al. 2015]. This is illustrated by a recent review of perception and social behaviour dealing with various natural hazards including floods, earthquakes, and volcanic eruptions [Wachinger et al. 2013]. The review found no consistent influence of multiple personal factors (including age, gender, and level of education) on individual risk perception, despite widespread academic belief that these factors are influential [Wachinger et al. 2013]. The only definitive drivers of volcanic risk perception were (1) communication and trust between authorities and locals, and (2) direct previous experience of hazards. Furthermore, these drivers are themselves volatile: as volcanic eruptions rarely develop consistently, they will variably affect surrounding populations. Thus risk will vary even between neighbouring communities around the same volcano [Donovan et al. 2012].

Local knowledge has the advantage of coming from direct experience of activity [van Manen 2014]. Recent research shows the importance of including local peoples' experience in managing volcanic risk, including in decision-making during crisis. Recognition of the flaws in a traditional linear approach to communicating risk [Donovan et al. 2014], successful integration of local and academic knowledge for participatory risk mitigation [Cronin et al. 2004], and proof of situations where locals have hazard knowledge equivalent to scientists [Gaillard 2008] have all highlighted the valuable contributions that local knowledge can make to understanding volcanic risk. Conversely, a failure to integrate local and institutional knowledge often proves ineffec- tive in reducing volcanic risk to the most vulnerable [Gaillard and Mercer 2013].

Storytelling is an aspect of local knowledge that may be particularly important for volcanic risk mitigation. Many disparate populations have used oral tradition to comprehend the trauma of a volcanic eruption [Cashman and Cronin 2008]. Although telling stories to understand volcanic eruption occurs in both pre-literature and literate societies, this method has largely been neglected in modern volcanic hazard mitigation strategies [Cronin and Cashman 2016]. Fortunately, this is changing. Storytelling through digital film has been used to sustain cultural memories of volcanic eruptions, with inspirational outcomes [Hicks et al. 2017]. The power of storytelling for building resilience to natural hazards in the Global South is increasingly recognized [Van Loon et al. 2020]. Storytelling for future disaster prevention is recognized in research disciplines beyond natural hazards, such as technical safety [Hayes 2018]. In this discipline, the responsibility for incorporating storytelling into disaster management strategies lies with professional safety managers [Hayes 2018]. Our paper includes stories told by local residents around Fuego to illustrate how storytelling may contain powerful truths about volcanic risk mitigation.

An emerging area of volcanic risk research is showing how different stakeholders focus on different periods of eruptive activity. Dove [2008] explored local and government perspectives of Mt Merapi's activity to argue that not only 'risk perception' but even the conceptualisation of risk itself varies. At Mt Merapi, locals contextualized changes in volcanic behaviour within their focus on long periods of calm, while authorities focussed on Mt Merapi in times of crisis and thus separated it from daily life. While it is uncontroversial to state that a volcano demands more attention from authorities during an eruption, this difference in focus between stakeholders and consequent implications for volcanic risk and its mitigation has been little explored in other countries.

In contrast to most complementary literature, this paper explicitly studies "direct experience (of previous eruptive activity)" as opposed to "volcanic risk perception". We believe that focussing on the latter isolates volcanic risk as the only risk people face in a volcanically active environment. Instead, "volcanic risk perception ... is one form of risk perception balanced with other forms of perception including risks to livelihood and cultural heritage" [Gaillard 2008]. We hope that by focussing on how different people experience eruptions, we can contribute towards more complete understanding of responses to volcanic activity of Fuego.

\subsection{Factors affecting evacuation}

The most effective action to mitigate risk to life from most volcanic hazards is evacuation. The decision 
to evacuate is often difficult to make because all choices may have negative consequences. An individual may decide to reduce personal risk when an eruption reaches its climax. This decision may involve evacuation, particularly if the hazards associated with the eruption are impossible to manage from that individual's current situation. But what factors influence the decision to evacuate, and which are inconsequential? Recent literature suggests that risk awareness appears not to be a primary factor. While direct experience of hazards may increase risk perception, it does not necessarily lead to better preparedness [Johnston et al. 1999]. Wachinger et al. [2013] attribute this weak link between risk awareness and preparedness to three potential causes: first, experience and motivation (e.g. an individual understands the risk but perceives that benefits outweigh risk); second, trust and responsibility (e.g. individual understands the risk but transfers responsibility elsewhere); third, personal ability (e.g. individual understands the risk but does not have resources to affect situation). Often the three causes can intersect. For example, at Montserrat, peoples' premature return to the exclusion zone was driven by factors varying from economic hardship to a lack of shared thresholds of tolerable risk [Barclay et al. 2008]. To outsiders, behaviour such as returning to an exclusion zone may seem illogical, as it increases threat to life. Before making such a judgement, they should seek first to understand temporal and spatial changes in social, political, and economic factors, as well as changes in volcanic hazard and responses to risk, all of which may encourage return [Few et al. 2017]. Responses to risk are related to local peoples' priorities, which themselves are often closely linked to the existing social and economic pressures that place individuals at risk. Pressures that encourage evacuees to return while risk is still high can be summarized as "push" (e.g. poor shelter conditions) or "pull" (e.g. concern for livestock) factors [Barclay et al. 2019]. These pressures, as they express a desire to act against further impoverishment, may interfere with an otherwise apparently more logical desire to protect life.

Local actions labelled as "illogical" may instead be driven by misunderstandings arising from poor communication between stakeholder groups that lead to disagreement regarding the nature of the risk and a disincentive to evacuate (e.g. in the reoccupation in the town of Baños near Volcán Tungurahua described by Lane et al. [2003]). In addition to breakdowns in communication, difficulties in evacuation management may occur because of peoples' resistance to leaving an area of high risk [Mei et al. 2013], driven by factors such as place attachment and security fears. Mei et al. [2013] identified five interrelated factors negatively affecting successful evacuation, including uncertainty in forecasting eruption and resistance associated with economic factors. Conversely, good communication and a shared understanding between different stakeholders may result in a shared commitment to participate in risk mitigation [Andreastuti et al. 2019]. An example of effective collaboration between stakeholder groups comes from Tungurahua, where trust between local vigias (watchmen) and scientists permits effective risk communication and evacuation processes [Armijos et al. 2017]. In this case, trust has evolved together with improved shelter conditions, evacuation routes, and resources together with possibilities for locals to maintain livelihoods inside and outside of the risk zone.

Although eruptions from Fuego have frequently triggered evacuation and disrupted the lives and livelihoods of local residents, few studies explore the link between volcanic activity and evacuation at this volcano. Early literature studied risk through the lens of human and agricultural vulnerability to volcanic hazards [Bonis and Salazar 1973]. Although Fuego had not caused significant damage to surrounding populations, the authors presciently detail possible future losses, astutely observing that "the human problems faced by the geologist on the site not only will be repeated, but may be increased manifold in the future." [Bonis and Salazar 1973, p84]. The next similar study, conducted among communities on Fuego's south-west flanks, discovered high awareness of volcanic risk coupled with widespread normalisation of Fuego's behaviour among locals, and increased risk awareness with age [Graves 2007]. These findings were confirmed by León-Ramírez Carné [2012], although this study found that awareness did not translate to a willingness to evacuate. The most recent study of volcanic risk at Fuego was conducted by Escobar-Wolf [2013] to consider situational and perception variables in decision-making during volcanic crisis. This work consisted of a pilot study in 2009 involving 38 individuals that informed a quantitative survey conducted in 2010 with 155 individuals in 8 communities around Fuego [Escobar-Wolf 2013]. These studies showed that locals frequently faced the decision of whether to evacuate or not from an eruption. Factors affecting the decision to evacuate included fear of looting and poor shelter conditions. This study made an enormous contribution towards understanding of population demographics around Fuego, including a summary of the complex origin and development of rural communities from plantations subsequently transformed by resettlement policies following the civil war years (1960-1996). While not explored in depth, such information contextualized the (un)willingness of local residents to evacuate their homes due to Fuego's behaviour. Additionally, this study determined quantitatively that willingness to evacuate from future eruptive crisis would be influenced by the conditions under which evacuation took place. However, this work did not explicitly compare direct experiences of activity between local residents and authorities. Our paper thus contributes to the debate on eruption and evacuation at Fuego through study of comparative experiences to understand the conditions under which evacuation does or does not take place. 
2.3 Providing context: eruptive history of Volcán de Fuego and associated stakeholder groups

Within the last 450 years, Fuego has produced at least 60 summit eruptions that usually manifest as shortlived explosive events producing pyroclastic flows and tephra fall [Rose et al. 2008]. A sub-Plinian eruptive sequence in 1974 was followed by two decades of quiescence. Since its reactivation in May 1999, Fuego's behaviour has been characterized by persistent Strombolian activity and lava flows. Fuego entered a new eruptive regime in January 2015 associated with more frequent explosive paroxysmal eruptions that form part of a repeated cycle of activity [Naismith et al. 2019]. These recent explosive paroxysmal eruptions ("paroxysms") consist of three stages where the central, most intense phase consists of 24-48 hours of intense activity involving a sustained eruptive plume, continuous explosions, and occasional pyroclastic flows. A full description of this activity is given in Naismith et al. [2019]. We use "paroxysm" in this paper to describe this activity that is characteristic of Fuego.

Volcanic risk mitigation at Fuego is managed through a network of institutions and the community. Table 1 defines acronyms of several institutions in this network. Figure 1 shows how these institutions communicate between themselves and with the public. INSIVUMEH was founded in 1976 after the 1976 Guatemala earthquake. The institution is responsible for monitoring geophysical phenomena and advising the government and private sector on natural hazards. INSIVUMEH monitor volcanic activity through a geophysical monitoring network managed from a central office in Guatemala City, aided by visual observations via two observatories in the communities of Panimaché Uno (OVFGO1) and Sangre de Cristo (OVFGO2)* The observatories are staffed by observers also resident in those communities. CONRED was founded in 1996 to reduce the impacts of disasters on Guatemalan society and to co-ordinate relief efforts. CONRED carries out training in hazard awareness and preparatory actions in communities around Fuego. This is achieved primarily through a subsidiary office, UPV (Unidad para Prevención en Volcanes) in Antigua Guatemala which organizes voluntary community groups known as COLREDes (Coordinadora Local para la Reducción de Desastres) in local communities. Communication between UPV and a COLRED is maintained via in-person visits, WhatsApp, and radio. Radio UPV is the network of community radio bases. As of April 2019, UPV had radio bases installed in 28 communities and two private farms (fincas) around Fuego. Each community radio base is housed by a radio operator who also belongs to that community's COLRED. Participation of COLRED

${ }^{*}$ After the events of $3^{\text {rd }}$ June 2018, Sangre de Cristo was evacuated and its observer relocated to Panimaché Uno. By the end of my fieldwork in April 2019, this observer was still in Panimaché Uno and working at OVFGO1. members in WhatsApp chats is highly variable due to inconsistent phone signal and costs of mobile data preventing local peoples' access to the conversation.

Policy is a primary factor determining the success of evacuation from volcanic crisis. As of June 2020, a policy of auto-evacuación (self-evacuation) is being actively promoted by CONRED at Volcán de Fuego. This policy requires active involvement of a community in decision and responsive action. The decision to evacuate a community from activity of Fuego should be made in agreement between a community's COLRED and its local council or COCODE (Consejos Comunitarios de Desarrollo). Furthermore, in the selfevacuation policy, a community is supposed to manage the initial stages of evacuation including gathering family members, moving to a pre-defined safe point, and beginning to leave a community on foot or by vehicle if necessary. Communication would ideally be maintained with UPV throughout evacuation. Theoretically, a community which initiates its own evacuation would find a secondary response co-ordinated by UPV involving temporary evacuation shelters and transport from the safe point to the shelters. In reality, several factors prevent this policy from working as it should; these factors are explored in Section 5. A full description of the roles of CONRED and INSIVUMEH can be found in the National Response Plan on CONRED's website (https://www . conred. gob. gt/site/Plan-Nacional-de-Respuesta).

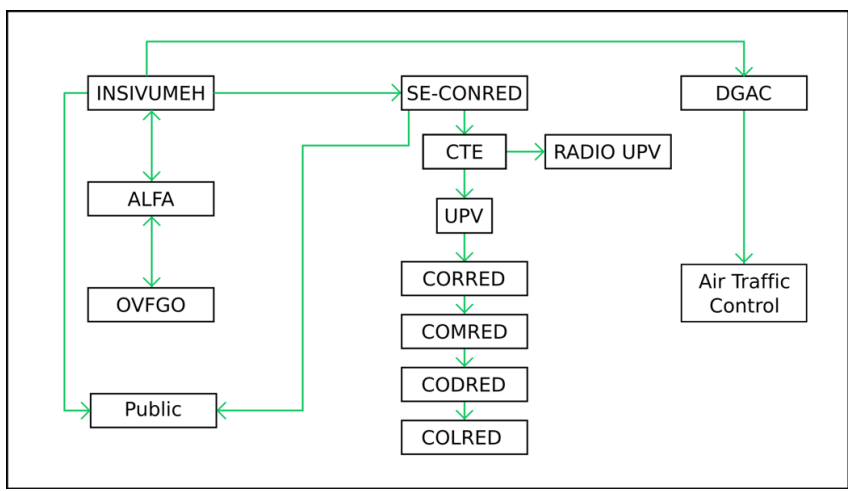

Figure 1: Schematic of different institutions and communities affected by activity of Volcán de Fuego showing pathways of communication between them. Diagram co-created by G. Chigna, W. Chigna, and A. Naismith.

INSIVUMEH prepare bulletin reports that are published on their website (www.insivumeh.gob.gt) and on social media, and delivered to CONRED. Published reports are further disseminated through WhatsApp and CONRED's radio network. The pathways of communication between institutions and the public regarding eruptive activity of Fuego are illustrated in Figure 1 . While in theory the roles of INSIVUMEH and CONRED are distinct, there is no single piece of documentation that clearly separates their responsibilities, 
Table 1 - List of acronyms used in this text. All acronyms relate to institutions involved in managing volcanic risk at Fuego.

\begin{aligned} & \hline Acronym Institution \\ & \hline ALFA INSIVUMEH's centre of communications for information dissemination \\ & CTE CONRED's centre of transmissions of emergencies \\ & COCODE Community Development Council \\ & COLRED Local Co-ordinator for Disaster Reduction \\ & DGAC Civil Aviation Authority \\ & OVFGO1 Observatory One of Volcán de Fuego \\ & OVFGO2 Observatory Two of Volcán de Fuego \\ & INSIVUMEH National Institute of Seismology, Volcanology, Meteorology, and Hydrology \\ & SE-CONRED Executive Secretary of CONRED \\ & UPV Union for Prevention in Volcanoes \\ & RADIO UPV Network of community radio bases managed by UPV \\ & \hline\end{aligned}

and in practice the institutions' efforts frequently overlap. This confusion has implications for personal and institutional responsibility for volcanic risk mitigation at Fuego.

\section{Methods}

In order to study experiences of previous eruptive activity and factors affecting evacuation, we chose qualitative data collection methods because of the flexible and exploratory approach to research they afforded, and because they allowed in-depth understanding of the motivations and interactions between different stakeholder groups. This paper is a case study, a "detailed study of a single class of phenomena" [Flyvbjerg 2006] which is valuable because of its depth of focus. Our study is informed by previous similar case studies such as Jóhannesdóttir and Gísladóttir [2010] and Stone et al. [2014]. We chose in-depth interviews as our main study method to facilitate discussion with participants about their experiences, similar to Jóhannesdóttir and Gísladóttir [2010]. As mentioned in Section 2.2, the most recent study capturing local experiences of eruptive activity at Volcán de Fuego was in 2007. Therefore, interviews provided an opportunity for better understanding of "[a] phenomenon about which little is yet known ... to gain more in-depth information that may be difficult to convey quantitatively" [Hoepfl 1997]. Our paper is published from the results of the lead author's thesis, which includes theoretical assumptions and philosophical stance involved in her research [Naismith 2020].

We collected our findings in two studies: first, a pilot study involving interviews with INSIVUMEH and CONRED staff in 2018; second, a study of experiences of local people, supplemented by those of INSIVUMEH and CONRED staff, in 2019. Both projects were ap- proved by the University of Bristol Ethics Committee. All participants in the 2018 project were already known to the interviewer and were approached individually. People interviewed in 2019 were recruited through a mixture of purposive sampling [Palinkas et al. 2015] and 'snowball' sampling [Atkinson and Flint 2004]. Interview data was supplemented by participant observation, a non-intrusive data collection method involving observing and participating in community activities [Atkinson and Flint 2004].

In total, 37 interviews were completed and audiorecorded, of which 32 were with local residents of the slopes of Volcán de Fuego and five with officials from INSIVUMEH and CONRED. Interviews were held in nine communities and a golf resort near the volcano (Figure 2). INSIVUMEH and CONRED staff were interviewed in Antigua, Alotenango, and Guatemala City. To preserve confidentiality these people are referred to as "Official" when quoted. Table 2 gives demographic data of local residents who gave recorded interviews in 2019.

Interviews were held in Spanish. Before an interview, permission to record it was sought from participant(s). The interviewer also explained to the participant(s) the interview's purpose and how the data would be used. The interviewer clarified to participants that any information they provided would be treated confidentially. To redress some peoples' wariness of appearing ignorant when discussing a volcano with a volcanologist, the interviewer explicitly stated that she wished to hear stories of Fuego from those who had knowledge that she did not.

Interviews involved the use of questionnaires involving open questions categorized by theme ${ }^{\dagger}$; nevertheless, interviews could meander to explore interesting deviations. Questionnaire design was guided by Bird

\footnotetext{
${ }^{\dagger}$ The questionnaires used in this study have been included as Supplementary Material in English and Spanish.
} 


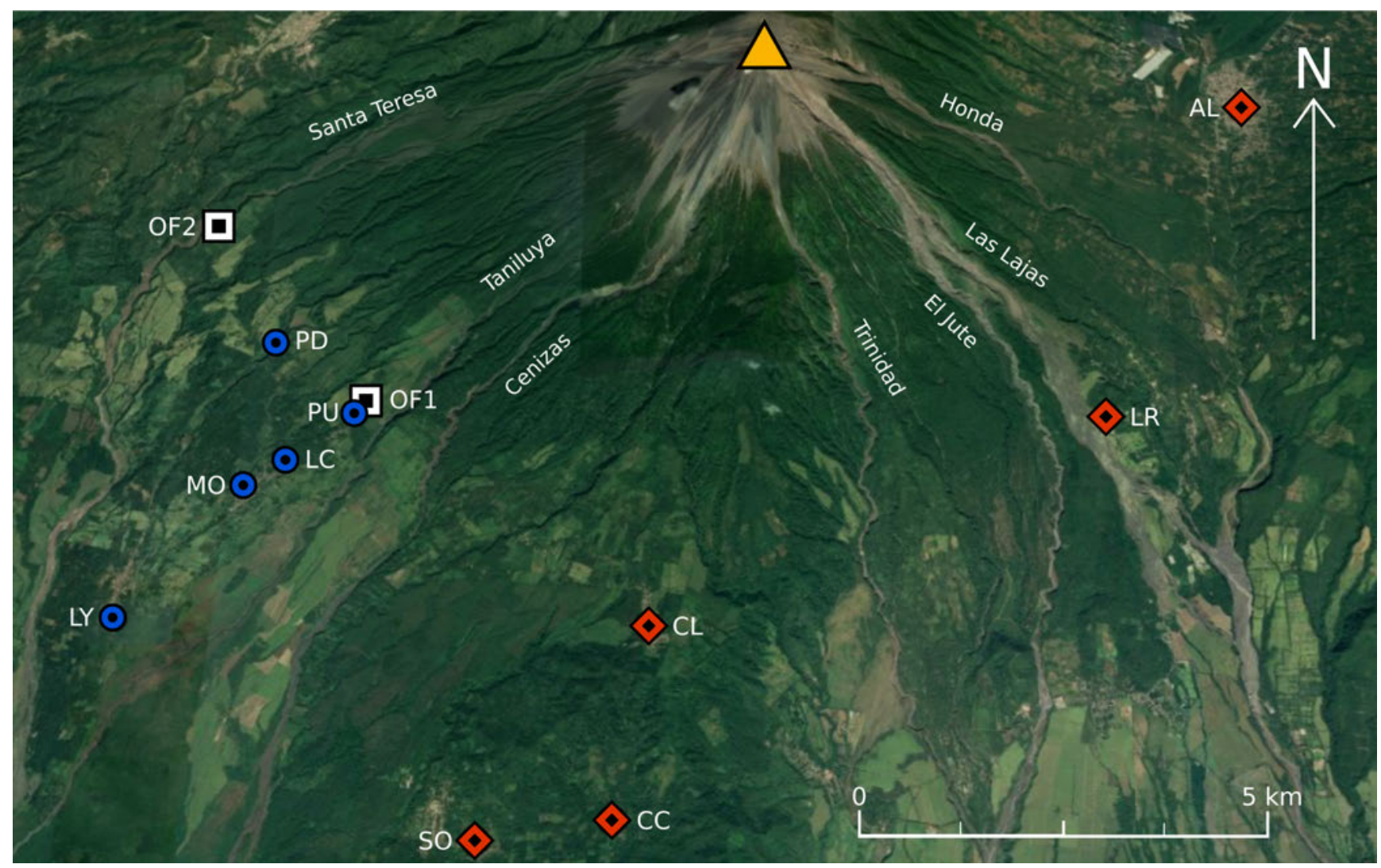

Figure 2: Map of locations visited at Fuego in 2019. Blue circles represent communities on west flanks: LC (La Colonia), LY (Los Yucales), MO (Morelia), PD (Panimaché Dos), PU (Panimaché Uno). Red diamonds represent communities further east: AL (Alotenango), CC (Chu-chu), CL (Ceilán), LR (La Reunión), SO (San Andrés Osuna). White squares represent INSIVUMEH observatories: OF1 (Panimaché Uno) and OF2 (Sangre de Cristo, permanently evacuated since June 2018). Large yellow triangle represents summit of Fuego (3763 m). Barrancas are labelled. Map data: Google Earth [2020].

Table 2 - Demographic data of local people who gave recorded interviews during 2019 study. People under 18 years old were not invited to participate due to additional ethical approval requirements. Initials for locations are same as for Figure 2. Note that number of participants in this table $(n=35)$ does not match number of recorded interviews with locals $(n=32)$ because three interviews contained two participants.

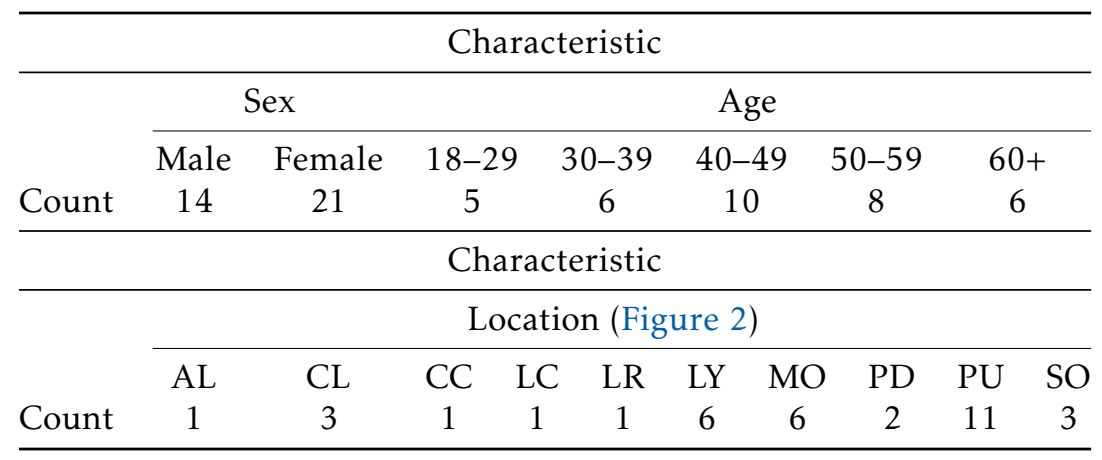

[2009]. Interviews were recorded with an Olympus WS-853 digital voice recorder. After interview, notes were added to a master Excel spreadsheet and interviews manually transcribed into written Spanish. The transcripts were loaded into NVivo software ${ }^{\ddagger}$ and subjected to thematic analysis to generate "codes", or units

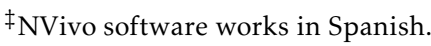

of meaning in transcript data that had potential analytical significance. We analysed our material inductively, allowing for themes to emerge, and "building from particulars to general themes" [Cresswell 2014]. Our inductive approach to thematic analysis was informed by Pistrang and Barker [2012]. To distinguish the most significant themes, we performed iterative 
coding, where inductively derived codes were applied to transcripts and field notes, which were then re-read and analysed to generated additional codes [Ritchie 2003]. Codes included single words (e.g. 'evacuación' or 'evacuation') and phrases referencing local experiences (e.g. 'Oct 1974'). This process allowed us to identify the themes that form the results of this paper, which include: a disparity between communities on Fuego's east and west flanks in terms of experience of previous eruptions and communication with INSIVUMEH and CONRED; effects of experiences of $20^{\text {th }}$-century eruptions on peoples' responses towards recent activity of Fuego; and vast differences in the way locals and nonlocals focussed attention on eruptive activity at Fuego. Quotations illustrating these themes have been translated from Spanish and included in Section 4 along with the community location (west or east flanks) to further validate the results. For readers of monochrome version of this paper, west communities are represented by circles in Figure 2, communities further east by diamonds.

\section{Results}

Results are divided thematically into the following subsections: 4.1 How different people experience volcanic activity; 4.1.1 Differences in focus; 4.1.2 Significance of previous large (VEI $\geqslant 2$ ) eruptions; 4.2 Factors affecting evacuation; 4.2.1 Trust between stakeholder groups; 4.2.2 Responsibility for decision-making and self-evacuation policy. Section 5 (Discussion) also follows this structure.

\subsection{How different people experience volcanic activity}

\subsubsection{Differences in focus}

We found substantial differences between how locals and authorities experience eruptive activity of Fuego. Locals observe that Fuego's activity has increased since 1999; however, they report that they have neither observed nor experienced the sudden increase in explosive paroxysmal eruptions since 2015. When asked how many eruptions had occurred within the past five years, locals frequently estimated fewer than ten. Furthermore, when asked about a specific eruption, locals frequently replied that it did not happen. For example, in March 2019 a resident of Panimaché Uno stated that the only eruptions in the last two years were those of June and November $2018^{\S}$. Nevertheless, local people see Fuego as persistently active, with flares of activity set within periods of calm. Smaller eruptive events in 2015-2018 are reported as paroxysms by INSIVUMEH

\footnotetext{
§INSIVUMEH recognized four explosive paroxysmal eruptions in this period: those beginning $31^{\text {st }}$ January, $3^{\text {rd }}$ June, $12^{\text {th }}$ October, and $18^{\text {th }}$ November 2018. No paroxysms occurred between January 2019 and June 2020.
}

but are seen by locals as periods of unrest only, describing these periods as "thunder" or "rumbling". Local people often connected descriptions of eruptive activity with a sense of having become accustomed to the activity. This was true of activity they experienced both before and after June 2018. The resident below speaks of activity after June:

\section{Resident of Panimaché Dos (West): \\ Sometimes we think it's only going to make rum- bles again, or ash fall, or a bit of arena (sand) will fall, and then it'll pass. So, that has allowed some of us to stay here. We are already used to the rum- bles and we have this already as an experience- that the rumbles don't scare us any longer, nor do the flares of fire that appear each night.}

When we asked local people about previous eruptive activity of Fuego, they classified only the largest paroxysms since 1999 as "eruptions". Locals did not distinguish between Fuego's activity pre- and post-2015 and this was consistent across age and location. By contrast, INSIVUMEH and CONRED staff observed a change in the frequency of paroxysms at Fuego similar to satellite observations:

\section{Official 1:}

And then we arrived in 2015, when the eruptions were very frequent, almost every 20 days. 15, 20 days, there were eruptions with pyroclastic flows, effusive ... in 2015 there were 15 eruptions, in 2016, 16 eruptions. In 2017 the number had dropped already, 9 in the year... including a very large eruption in May 2017 ... So we are waiting, see, to see what will happen. Because just as it changed in 2015, there could be another change so the activity decreases again, to how it was before. But it's still uncertain, how can we know what will happen?

Figure 3 illustrates the difference between observations by local residents and by satellite of Fuego's activity in 1999-2019. Official descriptions of activity closely mirror satellite observations, particularly since 2015, as quoted above. All eruptions illustrated by orange arrows resulted in widespread evacuations of local communities [Escobar-Wolf 2013]. Figure 3 contrasts these observations to show that both local and scientific observations are valid experiences of previous eruptive activity of Fuego. Our interpretations of this figure appear in Section 5.1.1.

\subsubsection{Significance of previous large $(V E I \geqslant 2)$ erup- tions}

How important is past experience in determining present views of risk at Fuego? Locals remember two major eruptions in the $20^{\text {th }}$ century: one sometime in 1966, and the VEI-3 eruption of October 1974. The 


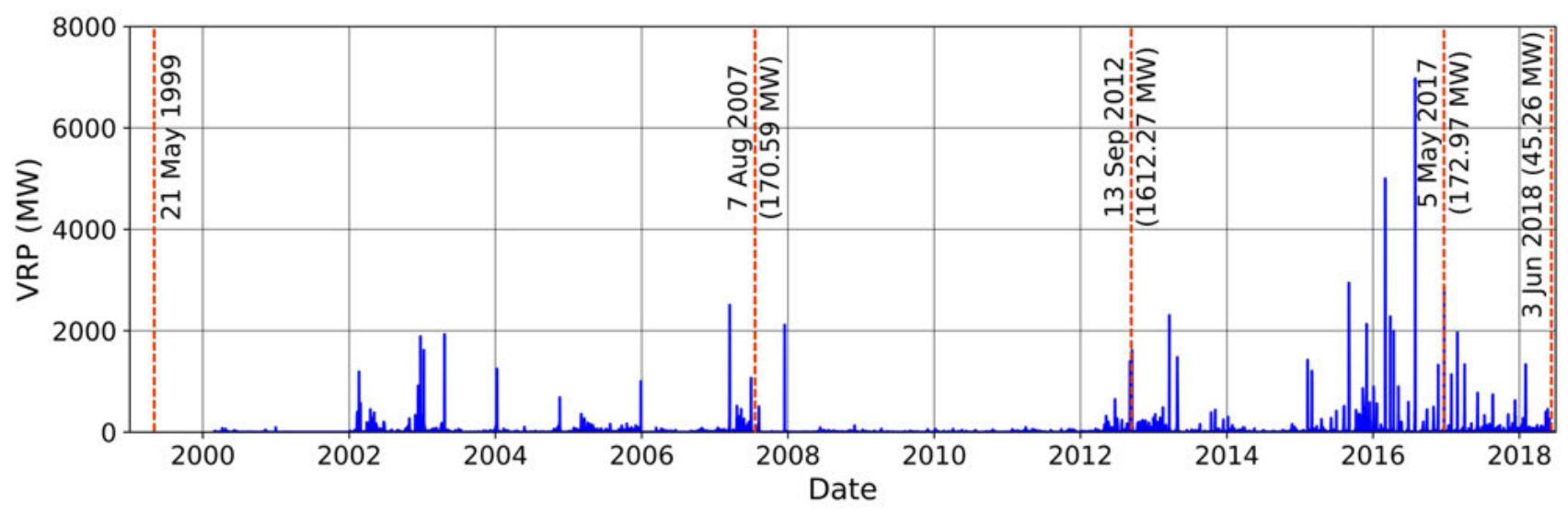

Figure 3: Contrasting local experiences of eruptions with satellite remote sensing observations. Orange dashed lines represent local experiences of major eruptions 1999-2019, while blue timeseries represents satellite-based thermal timeseries data derived from MIROVA night-time values of Fuego activity 2000-2018 (adapted from Naismith et al. [2019]). Each one of the eruptions highlighted by locals is associated with largest MIROVA value for that eruption, where possible.

precise date of the 1966 eruption was uncertain, but all testimonies in 2019 agreed it was extremely powerful, denoting either Feb 7

\section{Resident of Morelia (West):}

So, we were playing marbles... when it made the rumble, the thunder, like a bombshell. And it rose like a mushroom, a rising bubble, and it spread. And at that moment the rays of the sun were obscured, and we remained in darkness. Only 15 minutes from the start of the explosion, $15 \mathrm{~min}$ utes and we were blind ... it was totally destroyed. The houses fell, the rivers ran dry ... and the arena (sand) fell, fell, fell, and lots of lightning, a lot of friction in the atmosphere, the clouds. ... and any trees which were still half alive were killed by the lightning. And all of the vegetation died. All of it.

All locals interviewed in 2019 who had experienced the 1966 eruption also lived on the west flanks of Fuego, in the communities of Morelia, Panimaché Uno, and Panimaché Dos (Figure 2). When these residents described the eruption, they focussed on its longlasting impacts, in particular its devastating effect on agriculture and associated livelihoods:

\section{Resident of Morelia (West):}

The sad thing is that my generation ... until 2000, from 66, until 2000, lost any agriculture. Because now no-one could farm. No-one could harvest anything because nothing would grow. And we tried it, those of us who were already farmers, we tried. It didn't work. And those who were born in a land which is not for farming... they did not learn anything. Here nothing was produced and the easiest thing is to leave.
It was not possible to meet anyone on the east of Fuego who had directly experienced either the 1966 or the 1974 eruption. However, several residents of Ceilán shared their grandparents' experiences of 1974, talking of fall of rocks three inches in diameter, and a descending darkness that caused the blinded birds to fly into trees in confusion. The fact that these stories have been passed down through generations shows that large eruptions form a key part of eastern local residents' experiences of Fuego's activity. However, these experiences were of a short, intense eruption. Communities on Fuego's eastern flanks did not in general evacuate [Escobar-Wolf 2013]. Descriptions further west emphasise the significant impacts that followed the 1974 eruption. Evacuations lasted weeks or even months, and as with 1966 the impacts of 1974 were extensive death of native forest and wildlife and soil damage that has left a lasting legacy for those that draw a livelihood from agriculture in these communities. Even in 2019 the impacts of these eruptions remained: while locals on Fuego's east flanks stated, "the land here is very good land", western locals agreed that to find good land one had to dig. A resident of Morelia explained, "the volcano brings more poverty ... one has to make a hole to [one metre] depth, to reach the good soil."

Experiences highlighted by western locals in 2019 are consistent with existing literature on the 1974 eruption, including isopach maps showing principal tephra deposition towards the SW (Figure 4). Locals use the term piedra ("stone") to describe tephra fall in 1974. Size cannot be quantified precisely through description, but the use of piedra alludes to the eruption's severity. This is also true of the term arena ("sand"), which accumulated to a much greater depth in western communities (Table 3: compare 3 inches $(7.6 \mathrm{~cm})$ in Ceilán with $50-100 \mathrm{~cm}$ in Los Yucales). These terms have been left untranslated in following quotations to 
Table 3 - Community descriptions of tephra fall associated with the October 1974 eruptive episode.

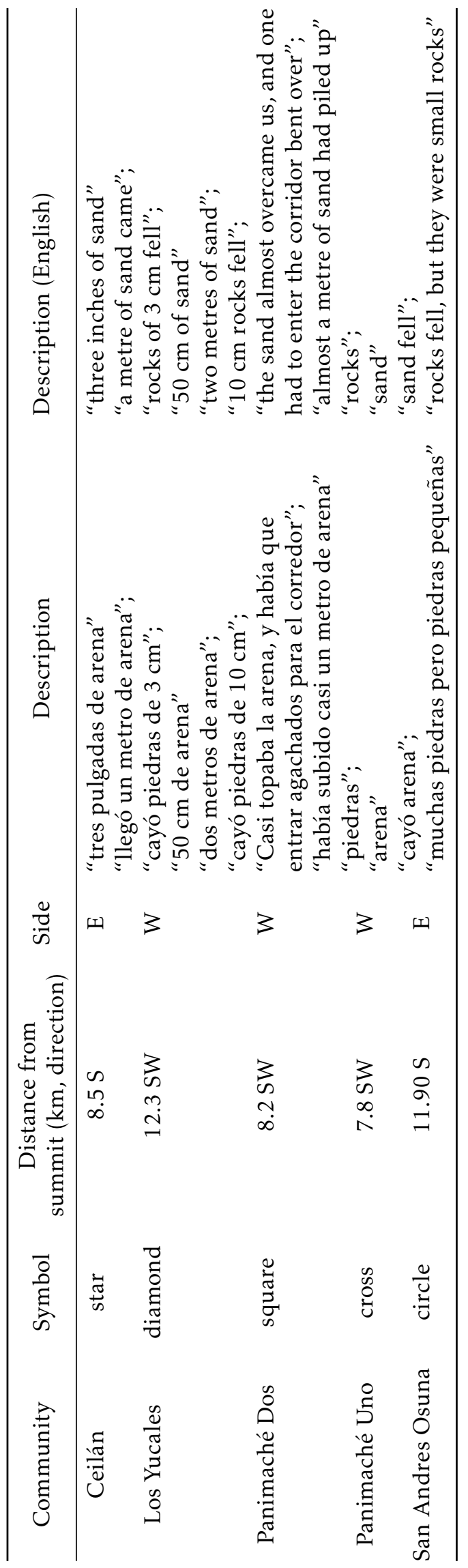

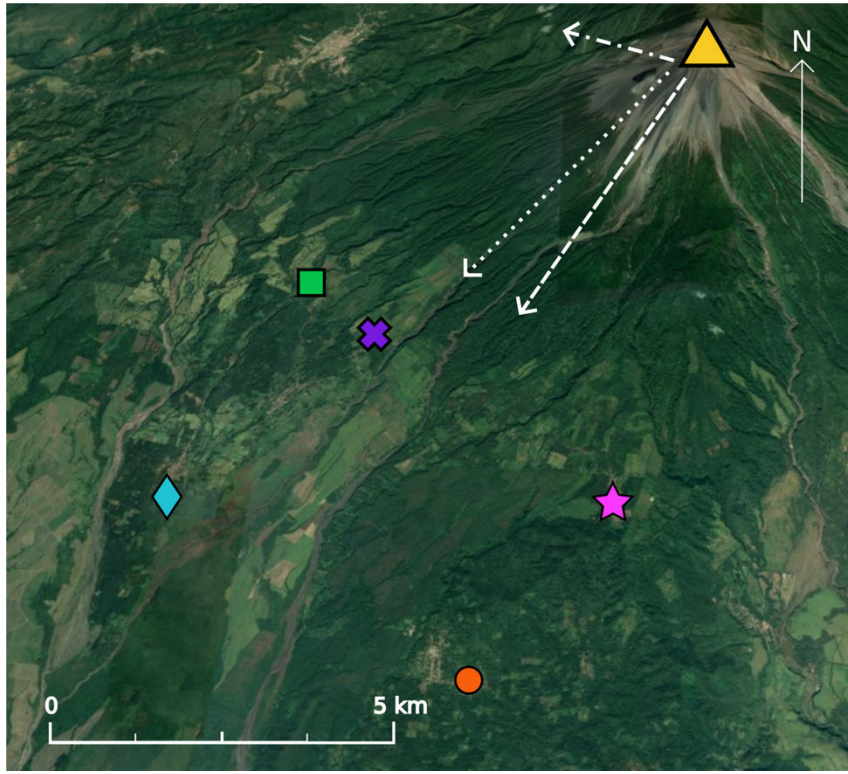

Figure 4: Local descriptions of tephra fall from the 1974 eruption. Symbols describe local communities: pink star (Ceilán), blue diamond (Los Yucales), green square (Panimaché Dos), purple cross (Panimaché Uno), orange circle (San Andres Osuna). Large yellow circle is summit of Fuego. Arrows represent wind directions of the October $14^{\text {th }} 1974$ eruption and show predominant wind direction towards WSW. Lines represent altitudes: dashed $\left(4000 \mathrm{~m}\right.$ altitude at $\left.215^{\circ}\right)$, dashed $\left(10000 \mathrm{~m}\right.$ at $\left.225^{\circ}\right)$, dot-dash $\left(7000 \mathrm{~m}\right.$ at $\left.285^{\circ}\right)$. Wind directions from Figure 4 of Rose et al. [2008]. Locals' verbatim descriptions of tephra fall are found in Table 3. Map data: Google Earth [2020].

preserve accuracy.

Many locals we interviewed in 2019 stated that the $3^{\text {rd }}$ June 2018 eruption was the largest eruption of Fuego they had seen. We reported in Section 4.1.1 that many locals had become accustomed to activity both before and after June 2018. The eruption was described as singularly powerful by all on Fuego's eastern flanks, who had less prior experience of severe eruptive impacts:

\section{Resident of Ceilán (East):}

[The eruption] began in the morning. And it was completely cloudless in the morning. But the error... was that this [activity] was already typical for us, we didn't give it much significance. Because we were already used to seeing this ... it's common. It's going to throw out lava again. It's ordinary. It's already throwing out ash. Everyone who has their crops up there, towards the main square, ash is going to rain on them. Normal.

This resident then described the pyroclastic flows generated by the eruption. They do not use the term "pyroclastic flow", but from its characteristics and 
through triangulation with other sources we can definitively conclude that this was the hazard observed. The lack of a specific term to describe pyroclastic flows was common among local people:

At eleven, twelve [o'clock], we began to see that
it started to throw out more, as if it were smoke.
We said, "Ah! What a humazon [cloud of smoke]
it's throwing out towards the other side!”. But
we didn't know the name of the material it was
erupting. And from then on, from midday on-
wards, we saw that it started to throw out mate-
rial this side too. .. But we saw that all this side
of the volcano, towards the side with Los Lotes,
we saw it as smoke, that is how it came. As if it
were an enveloping ball. As if it were a ball of
gas. It was buried like that.

Many people in western communities agreed that June 2018 was one of the largest eruptions they had seen. However, a notable exception was among older people in these communities. To them, the 2018 eruption was smaller in scale and impact than those of 1966 and/or 1974. They remarked on the difference in ash fall: arena and piedra in 1966 and 1974, and ceniza (ash) in 2018. Here a resident explains the different severities of eruption they experienced:

Resident of Morelia (West):

Resident: So that is the fear that we have. But I tell people, "You are all afraid of what the volcano is doing now, this is nothing!", I tell them.

Interviewer: "This is nothing"? So - lately, this is nothing?

Resident: Yes. But these that are - these eruptions are nothing compared to what I have lived, I tell them. Believe me that I, the day of that eruption, when everything went dark, a lot of arena fell. After that came another eruption. In which the arena was not fine sand so much as fine rocks.

Older locals considered the 2018 eruption minor compared to $1966 / 1974$, therefore did not evacuate in 2018. Another theme in older locals' responses was in how they determined eruptive severity. Several stated that their response to an eruption is determined by the type of ash fall:

\section{Resident of Los Yucales (West): \\ I stayed and set to thinking. I told them, "No". I told them, "No. Here... don't be afraid, my chil- dren, because this is ceniza. When arena falls, yes. When that happens, we must leave."}

This resident elaborated that their decision to evacuate would be influenced by ash fall. If it was fine ceniza, the eruption was not severe enough to require evacuation. When fall material resembled the arena that fell on western communities in 1966 and 1974, evacuation would be necessary.

\subsection{Factors affecting evacuation}

\subsubsection{Trust between stakeholder groups}

Communities around Fuego in 2019 had inconsistent levels of trust in authorities, with local opinion varying between complete faith in authority and total selfreliance. This variability was most clearly expressed in a striking difference between communities on Fuego's west and east flanks in terms of their communication with INSIVUMEH and CONRED. The presence of INSIVUMEH-owned observatories in the western communities of Panimaché Uno (OVFGO1) and Sangre de Cristo (OVFGO2, until June 2018) (Figure 2), and the regular visits of scientists from Guatemala City, builds locals' confidence in INSIVUMEH. Western locals appreciate the presence of the observatories and INSIVUMEH's role in issuing information during volcanic crisis. These factors have generated so much trust between locals and observers that some locals believe INSIVUMEH carries the responsibility for preparedness for an eruptive crisis. Many western locals, when asked about their decision to evacuate or not, stated that they could not distinguish when Fuego was becoming dangerous, and that they relied on advice from "up there" (OVFGO1 in Panimaché Uno) to tell them when to evacuate:

\section{Resident of Panimaché Uno (West): \\ Interviewer: And how did you know? What was the alert, the information?}

Resident: Because it came from INSIVUMEH up there. They advised us. They gave the alarm that we had to leave, so we got together in order to leave. They alert us in case we have to leave. If they don't advise anything, we do not leave. If the volcano is erupting, and they don't advise us, we don't leave. While they - we wait for their voice in order to leave.

In contrast to the good relationship between locals and INSIVUMEH/observers, western locals' interactions with CONRED were less positive:
Resident of Panimaché Uno (West):
[CONRED] supposedly their work is to look out for the communities, give talks, so that disasters don't happen. Right? But always ... CONRED never come to give talks. You've seen now that CONRED said, "One week on this side of Fuego, one week on the other" - and see, four weeks and they haven't come. They are always like this... they always fall short.

Residents of eastern communities were far less familiar with INSIVUMEH. They had neither an observatory nor familiar faces with which they could associate INSIVUMEH's work. Instead they knew CONRED 
through its sub-department UPV and their frequent visits to local COLREDes. Figure 1 gives an overview of how these groups communicate during activity of Fuego. COLREDes on Fuego's east flanks include volunteer participants who perform similar roles to observers at Panimaché Uno, acting as knowledgeable individuals who inform others of changes in eruptive behaviour and co-ordinating community response when Fuego is more active:

I - as I said, I work here in the COLRED for my community. [That time] I noticed the wailing. People were saying, "And when will we leave? What is going to happen to us?". And I said ... I have an example. One day - about three days after the tragedy, I was here living through difficulty. Take it from me, I had never lived through something like that, here on the side of the - and a woman called, "[Resident's name]! Over there you can see the lava! What should we do?". And I - with my training, I told her, "Well, let us leave, over there are my associates."

While western locals' trust in INSIVUMEH and its observers is evident, the level of confidence of eastern locals in their COLRED was less clear. The organisation and size of a COLRED is highly variable between communities and subject to rapid, unexpected change: in the nine weeks' duration of the 2019 study, at least two COLREDes were restructured. Motivation appeared higher among COLRED volunteers who host a community's radio, many of whom stated that this role was a source of pride. However, the politics of owning a radio are complicated. In several communities, ownership disputes have led to a breakdown in communication, either within the COLRED or between the COLRED and UPV. Happily, this difficult situation appears to be improving. In 2020, communication between 27 communities is regularly maintained, with reports of eruptive activity occurring four times daily (W. Chigna, personal communication). Participation in COLRED is a voluntary, unpaid role, and in 2019 many locals expressed that they were disincentivized to participate. This was partly due to a lack of recognition of the role from their community and partly due to inconsistent support from UPV. In 2019 we found that several COLREDes had infrequent contact with UPV and received little support from this entity that supposedly acts as advisor to, and co-ordinator of, COLREDes. One local said eloquently: "Why should we continue, when no side supports us?".

\subsubsection{Responsibility for decision-making and self- evacuation policy}

We began this paper by highlighting the different fates of San Miguel Los Lotes and La Reunión on $3^{\text {rd }}$ June. This relates to a larger issue of the willingness of communities to evacuate from eruptive crisis. In 2019 we found that understanding a community's (lack of) willingness to evacuate was still a central challenge for officials at Fuego:

\section{Official 4:}

They demand of us the answer, "Why did La Reunión leave?" - and it is true, they evacuated in time. "And why not the communities?".

All officials we interviewed spoke of the difficulty of successful evacuation of communities from eruptive crisis of Fuego. The official quoted above spoke of their experience in encouraging evacuation at Los Lotes:
When we were going through Los Lotes, we were going through warning them, with a siren and ev- erything. I did not see anyone come out. No one, no one. That is, no one expected that ... maybe they imagined that ... somehow, they could have escaped, if [the hazard] had come down the road. But they never imagined that it was going to come out from behind them.

As explained in Section 2.3, the decision to evacuate is co-ordinated between stakeholder groups at Fuego. Official responsibility for calling an evacuation at Fuego requires approval either from a community's COCODE or agreed between the community's COCODE and COLRED. In a crisis, self-evacuation policy would have these groups convene and agree to temporarily evacuate their community. Self-evacuation also makes local residents responsible for communicating their evacuation to, and requesting resources from, CONRED (via UPV). Self-evacuation was being promoted both before and after $3^{\text {rd }}$ June:

2018:

Interviewer: If an eruption like 1974 were to occur again, what would be a 'success' for CONRED?

Official 2: Success would be that everyone evacuates without us coming. That people call us to say they have begun evacuating, so that we can coordinate transport, how to catch buses and reach the shelters. Not that they call us, "Look, what shall we do, come here and get us", but that the decision is theirs and they evacuate.

Interviewer: So that they make the decision and communicate with you, and you are the ones that give support.

Official 2: Mm-hm. It is quite difficult.

2019:

Official 4:

Ultimately, I think things have changed. But not everything that we would have liked. What I mean is that possibly there is better risk perception. They know what it is, that there is a very 
serious risk. But ... but I don't think that the specific ways have been focussed on. For example, in the communities, people wait and see, in any situation in which it is worth evacuating, we have to come and remove them. Everyone. We have to send trucks, we have to send vehicles, transportation. Just like what happened on November 16. People did not leave on their own. ... a better example is, "My house is catching fire. I don't expect firefighters to come to take me out. I'll leave, I ...". That is, the first response comes - from the individual level, family level, right, and as a community, it is important. But I understand that it is also difficult.

While officials in 2019 stated that locals have better risk perception, this belief was not fully borne out by our interviews with locas. It is true that many people stated that they were newly aware of what Fuego could do to damage them:

\section{Resident of San Andres Osuna (East):}

Such a beautiful view, but today we know the ability, the capacity that this volcano has to destroy, don't we?

However, other locals did not appear to have increased risk perception. The resident from Panimaché Dos quoted in Section 4.1.1 represented the views of many locals who in 2019 had readjusted to Fuego's activity. Older western locals also expressed a diffidence towards the scale of the 2018 eruption that contrasts with the quoted statement of Official 4 above. Despite these instances of differing perspectives, our coding did show that, after the $3^{\text {rd }}$ June eruption, many locals would be prepared to evacuate when the situation demanded it:

\section{Resident of Panimaché Uno (West): \\ We saw how [Los Lotes] was left. Well, we are afraid, having seen everything that happened and waiting here. Better to leave... leave and not wait any more.}

We found strong consensus that it was better to leave immediately when Fuego began displaying signs of unrest rather than waiting for further increase in activity. Consensus was particularly strong in Panimaché Uno, where nine of the 11 people we interviewed stated this in some form. We suggest this relates to the strong relationship between locals and observers in OVFGO1 (see Section 4.2.1). However, while locals outside of Panimaché Uno also expressed desire to evacuate promptly, this desire was consistently tied to concerns about risks involved in evacuation. Risks mentioned included leaving houses unattended (thus vulnerable to looting), livestock welfare, and evacuation shelter conditionsor whether such shelters existed. A particular phrase, "a donde ir" ("where to go") was recorded in nine separate interviews with locals. Locals employed this phrase to express uncertainty regarding evacuation.

We were able to directly interview staff at $\mathrm{La} \mathrm{Re}$ unión golf resort. This gave us direct insight into factors affecting the resort's decision to evacuate in June 2018. From interviews with La Reunión staff and INSIVUMEH/CONRED staff who had worked with them, we found that La Reunión had implemented a culture of preventative self-evacuation where guests and staff evacuated when an explosive paroxysmal eruption of Fuego developed. The crucial threshold for selfevacuation was the descent of pyroclastic flows below a certain height in visible barrancas [confirmed in Tobar 2018]. This threshold was not decided by La Reunión staff but by CONRED, who had regular communication with La Reunión management. La Reunión had evacuated several times before June 2018, most notably in the paroxysmal eruption of $31^{\text {st }}$ January- $1^{\text {st }}$ February 2018:

La Reunión staff 1 (East): But that one of February 2018, the first of February I think it was, it scared me a lot when I left the office here and I jumped to see the volcano, and I saw that this cloud, as if it had come above us - then it scared me. But then nothing happened, right? It was only fear!

Interviewer: A-ha, yes. So you stayed here?

Staff: No. We evacuated, that time we evacuated $\ldots$ and then on the next day we returned.

Interviewer: Ah. And in previous years when there were eruptions, ... was there a warning to evacuate or not?

Staff: Yes, they informed us. Yes. They always warned us that we had to evacuate.

From interviews we determined several factors facilitating a culture of preventative evacuation at La Reunión. Its position as a private resort allows management to force guests' departure; it enjoys good communication with both INSIVUMEH and CONRED; and resources such as $4 \times 4$ vehicles allow rapid escape. With all these advantages, staff argued that evacuation was still not simple:

\section{La Reunión staff 1 (East):}

What is complicated is that not everyone leaves. Some leave immediately, others we have to insist to them that they leave... they didn't leave, because always, "Why should we leave if nothing is going to happen", right?

We discuss these findings and their implications in Section 5.2.2. 


\section{Discussion}

We have divided the discussion into subsections that follow the structure of Section 4. Findings from Section 4 are discussed and we interpret them with reference to literature presented in Section 2. We also include the implications of our interpretations.

\subsection{How different people experience volcanic activity}

\subsubsection{Differences in focus}

In Section 4.1.1 we presented evidence for observational differences of Fuego's activity by local residents and by satellite (Figure 3). Observations by officials closely matched satellite data. What causes these differences? One reason is that officials have information that is unavailable to locals. INSIVUMEH's geophysical monitoring network detects changes in seismic activity at Fuego. These can be correlated with other information to which INSIVUMEH has access, like satellite imagery such as NASA's MODIS and LandSat platforms. While INSIVUMEH and CONRED staff's experiences of recent activity at Fuego correlate with satellite observations, this is likely because of coincidence with visual observations of Fuego's summit eruptive activity from OVFGO1 [Lyons et al. 2010; Naismith et al. 2019]. Visual observations from OVFGO1 (Figure 2) generally match satellite data because thermal anomalies detectable by satellite are also visually distinctive (e.g. incandescent fire fountaining). INSIVUMEH combine visual observations with other monitoring tools because frequent cloud cover frustrates observations of Fuego from surrounding communities. We reason that the fewer sources of information on Fuego that locals can access partly accounts for the difference in experiences between locals and officials.

A second reason for this difference could be the 'normalisation bias' encountered in other literature [e.g. Haynes et al. 2008]. Normalisation bias may impel locals to expect only the experienced, desensitising them to changing risks; this has previously been documented at Fuego [Graves 2007]. Our findings from interviews with locals in 2019 suggest many were accustomed to Fuego's eruptive phenomena (Section 4.1.1) Excepting uncommonly large eruptions such as September 2012, relative changes in Fuego's activity do not register with locals. In contrast, INSIVUMEH staff and CONRED staff face the volcano rather than use it as their backdrop. Their point of observation is different.

Although we conclude that locals do normalise Fuego's activity, we argue that this only partly resolves the difference between locals' and authorities' experiences of recent eruptive activity. Quotations from locals in Section 4.1.2 are rich descriptions that show how vividly they remember previous eruptions. We propose an alternative explanation: while any eruption since 1999 could have evolved into a larger event, few did, and therefore did not require communities to take responsive action. This response is the critical factor which preserves an eruption in local memory at Fuego. Notably, the isolated events that locals remember (e.g. September 2012, June 2018) were all associated with disruption of daily community life. This is substantiated by Figure 3: the orange arrows indicate both eruptions that caused evacuations, and eruptions that locals frequently described. Figure 3: shows the great difference in local and scientific foci on Fuego's activity. Crucial is that both views are partial: years of eruptive activity are not acknowledged by locals, while several eruptions that locals consider significant barely register in satellite data. For example, the eruption of $13^{\text {th }}$ September 2012 provoked the evacuation of thousands of people but produced a peak thermal radiance of 1612.27 MW, smaller than many events occurring since onset of the new eruptive regime in 2015 [Naismith et al. 2019]. By contrasting local and scientific observations in Figure 3, we are not trying to undermine the utility of scientific observations for understanding eruptive activity. Instead, we argue that both sets of observations are valid and need to be recognized in terms of what matters to different stakeholder groups around Fuego. Appreciating the difference between locals' and scientists' views is critical for effective future risk mitigation at Fuego, if these groups wish to collaborate to protect life and assets from eruptive activity. Throughout volcanic risk literature there is evidence that shared views of risk between stakeholders contributes to more effective risk mitigation procedures, for instance at Volcán Tungurahua in Ecuador [Armijos et al. 2017], at Sinabung and Kelud volcanoes in Indonesia [Andreastuti et al. 2019], and at Tristan de Cunha [Hicks et al. 2014].

We advocate here for a recognition of different points of view, rather than a resolution. Local people should not have to adapt to resolve this difference in focus on Fuego's activity (and consequently of its risk). The view of some scientists that local knowledge of volcanic risk as insufficient [e.g. Donovan et al. 2014] does not acknowledge that different points of view can coexist and be valid. As Dove [2008, p 336] states: "authority views of risk are themselves inevitably socially constructed and thus contingent in value and efficacy". Different views of volcanic risk stemming from different focuses on activity can explain conflicting responses to past eruptive crises at Fuego, and if unresolved these conflicts may be repeated in future. For example, during the November 2018 paroxysm, despite CONRED issuing a red alert and sending vehicles to aid evacuation, many locals refused to leave their homes [RT 2018]. In this case, risk was viewed as sufficiently high to require evacuation by authorities but not by locals. Accordingly, authorities considered that locals were underestimating risk, and conflict arose as the groups differed in their response (or lack of) to the perceived risk. An inverse difference in views of risk 
has also recently occurred at Fuego, when on $6^{\text {th }}$ June 2018 residents of communities in Escuintla observed behavioural changes of Fuego that they interpreted as a reactivation [G. Chigna, personal communication]. Many people evacuated and requested help from authorities that was not given. On this occasion, locals recognized a risk from Fuego that authorities did not acknowledge. Locals then desired a reaction that authorities did not feel responsible for. On both occasions, differences between stakeholder judgements of risk caused different responses and resulted in conflict. We believe that acknowledging multiple points of view would avoid such conflicts in the event of future eruptive crisis at Fuego.

\subsubsection{Significance of previous large $(V E I \geqslant 2)$ erup- tions}

In Section 4.1.2, we reported our findings on local experiences of eruptions in 1966, 1974, and 2018. Older locals in western communities describe the long legacy of 1966 and 1974 eruptions on agriculture. They described the 2018 eruption as lesser. In contrast, people in eastern communities described the 2018 eruption as larger than any they or their predecessors had experienced. Some of this disparity is due to fewer older interviewees in the east. However, the disparity seems genuine. Locals in Ceilán shared parents' stories of an acute event without long-lasting impacts. Differences in impacts are clear in Figure 4 and Table 3 (compare "three inches of sand" that fell in Ceilán with "two metres of sand" in Panimaché Dos). Given that communities around Fuego are separated by only a few kilometres, Figure 4 illustrates that previous direct experiences of volcanic activity can vary dramatically between even adjacent communities. This difference matters in influencing the decision to evacuate [Wachinger et al. 2013]. We also found that older western locals frequently compared 1966/1974 with 2018 in terms of severity (Section 4.1.2). That older locals experienced the 2018 eruption as relatively minor is key in evaluating volcanic risk at Fuego because of how these locals interpret the risk of an eruption, and subsequently their vulnerability and response. We conclude from their failure to evacuate in 2018 that locals would not do so until a future eruption is comparable to 1974 . This has problematic implications.

Local residents' descriptions of eruptive activity have been documented at Volcán Tungurahua, and the observations interpreted in terms of different eruptive processes [Armijos et al. 2017]. At Volcán de Fuego, we found a similar phenomenon where residents use qualitative assessment of tephra size as a method of evaluating eruptive severity. Furthermore, they include this assessment in their decision to evacuate. This speaks of a remarkable awareness of volcanic hazard among locals: their identification of changes in tephra fall is a clever form of monitoring. Furthermore, link- ing this change with different eruptive severities indicates some understanding that fall of larger tephra is associated with a more energetic eruption producing a strong eruptive plume capable of more widespread tephra dispersal and representing greater hazard. This finding demonstrates an impressive understanding of volcanic hazard. Nevertheless, we assert that evaluation of tephra size to decide response to Fuego's eruptions has potentially dangerous implications. Firstly, making the decision to evacuate when arena falls may already be too late. Secondly, this evaluation does not acknowledge other independently-occurring hazards, such as lahar or pyroclastic flow, that could put locals at risk. In 2019, people who reported distinguishing between arena and ceniza in determining response to eruption were located in Panimaché Uno, Los Yucales, and Ceilán (Figure 2). These communities all have evacuation routes that cross barrancas which could be cut off by lahars. Panimaché Uno also lies close to Barranca Taniluyá, a principal route for pyroclastic flow descent. As such, using only arena/ceniza to determine response to eruption may provide an incomplete assessment of hazards. Ameliorating volcanic hazard assessment is not solely the responsibility of local people, but should depend also on better information and its effective communication from INSIVUMEH and CONRED.

\subsection{Factors affecting evacuation}

\subsubsection{Trust between stakeholder groups}

Evacuation is a powerful tool when seeking to protect life during a volcanic eruption. However, it is complicated and often costly, thus often invoked only in crisis. The different fates of people in La Reunión and in Los Lotes on $3^{\text {rd }}$ June 2018 has been heavily scrutinized, often with the perception that wealth, and consequent access to resources and information, was the author of their destinies. This is debatable because the preventative evacuation that protected lives at La Reunión on $3^{\text {rd }}$ June also has precedence among rural communities with many fewer resources. Sangre de Cristo, for instance, has developed a practice of preventative evacuation since the eruption of $7^{\text {th }}$ August 2007, similar to the self-evacuations at Tungurahua reported in Armijos et al. [2017]. The ability to evacuate or not must therefore be determined by something more sophisticated than simply being rich, just as vulnerability is often correlated to, but not synonymous with, poverty [Blaikie et al. 2014].

The importance of trust in authorities is crucial in taking preventative action during crisis [Wachinger et al. 2013]. We found that local trust in authorities around Fuego in 2019 was inconsistent (see Section 4.1.2). Western locals had good trust in INSIVUMEH due to the presence of community-based observatories and regular visits from scientists in Guatemala City. A similar confidence occurs at Tungu- 
rahua between locals, vigías, and scientists from Quito [Few et al. 2017; Stone et al. 2014]. We found at Fuego that western locals were so trusting that they were willing to outsource decisions on evacuation to INSIVUMEH and the observers of OVFGO1, similar to the "trust and responsibility" cause cited by Wachinger et al. [2013] for the disconnect between risk perception and preparedness. Placing such trust in INSIVUMEH has ambiguous connotations. It may disincentivize locals to take personal measures to mitigate risk. On the other hand, it is essential in ensuring advice from INSIVUMEH will be considered during a crisis. This advice may decisively change local peoples' response to volcanic risk, either by the content of the advice itself, or more likely because the high levels of confidence in observers automatically renders the advice important, as seen with the vigías of Tungurahua [Stone et al. 2014]. However, this trust is complicated. Whether it is the vigía network and IG-EPN of Tungurahua, or the OVFGO1 observers and INSIVUMEH in western communities of Fuego, scientists do not have a mandate to call an evacuation. As such, if INSIVUMEH advises locals to evacuate due to activity of Fuego, it is not in an official context. This occurred in September 2012, when a widespread evacuation of communities was led by the observers of OFVGO1. Unofficially, several people in 2019 stated that this event was the impetus for CONRED's current policy of self-evacuation. However, it cannot be assumed that in future eruptive crises, other communities could carry out such an evacuation: for example, no communities other than Panimaché Uno have trained observers already resident. Indeed, the reliance on INSIVUMEH and observers for an informal evacuation alarm may lead to a conflict between local's and CONRED's judgements of risk and subsequent response (as discussed in Section 5.1.1). In addition, the lack of confidence in CONRED displayed by some western locals may dissuade them from complying with CONRED's advice during future eruptive crises. There are many other conditions that complicate the relationship and trust between authorities and residents of western communities, and more research is required to understand the situation better. However, our findings indicate that in the specific case of Panimaché Uno, recognition of different views and a closer relationship between residents and authorities has had a positive influence on local residents' willingness to evacuate.

Trust in authorities among residents of eastern communities was less clear than in the west. From interviews with local residents who are voluntary COLRED members, we found these residents considered their COLRED a trusted source of information in the community (similar to INSIVUMEH's observers at OVFGO1 in Panimaché Uno). However, while the trust between western locals and observers was ratified by locals' words, we could not confirm the extent of trust between eastern locals and COLRED members. Some members of COLREDes themselves expressed a lack of support from authorities. There are some parallels to be drawn between COLREDes and the vigía network at Tungurahua. The latter has flourished in part because volunteers feel they are playing a critical role in providing early warning of volcanic activity and contributing to risk mitigation [Stone et al. 2014]. Contrary to the "trust and responsibility" clause cited in the previous paragraph, a lack of trust in authorities has multiple effects on local peoples' perspective and behaviour, including an increased tendency to underestimate risk and a reduction in willingness to take preparatory actions against risk from natural hazards [Wachinger et al. 2013]. Therefore, we promote support of existing COLREDes in eastern communities at Fuego, as in the absence of a permanent observatory a voluntary network may be the best line of communication between locals and authorities. We found interesting dynamics in being a COLRED radio operator: on the one hand, it was an important source of pride, but on the other, it could inspire envy. In the comparable vigía communication network at Tungurahua, a radio is used as a shared resource that provides an important informal communication pathway [Stone et al. 2014]. A practical way to support COLREDes could be to maintain the radio network with good batteries, ongoing training, and encouraging commitment in participating in reports.

\subsubsection{Responsibility for decision-making and self- evacuation policy}

Supporting COLREDes is also important for the success of the self-evacuation policy at Fuego in future eruptive crises. Set-up of a community COLRED is not trivial. UPV is responsible for volunteer recruitment and training. However, once founded, a COLRED is supposed to act as a separate entity. Members of a community COLRED are supposed to act as a source of information for the community and advise the COCODE on whether to evacuate during volcanic crisis. Based on this structure of responsibilities and the quotations from officials in Section 4.2.2, the presence of COLREDes appears to be an attempt to transfer more responsibility for volcanic risk preparedness to local people by CONRED. However, it is uncertain whether a newlyfounded COLRED and its members have sufficient knowledge and training to perform equivalent work to INSIVUMEH in advising a COCODE in times of crisis. While Section 4.2.1 illustrates that locals have good knowledge of Fuego's eruptive hazards drawn from direct experience, this does not translate to an ability to distinguish when such hazards have reached a critical level requiring evacuation. Furthermore, although we interpret the creation of COLREDes as a transfer of responsibility for decision-making from CONRED to local residents, it is unclear whether residents accept this responsibility. In fact, there is no clear evidence for a lessening in locals' belief that CONRED are responsible 
for decision-making and initial response during eruptive crisis. The differences between local and authority views of responsibility for decision-making, and implications for success of self-evacuation policy, are discussed in more depth below.

The self-evacuation policy contains assumptions about local knowledge, resources, and experiences that conflict with quotations from local people. Assumptions of knowledge are implicit in quotations by officials in 2018 and 2019 (see Section 4.2.2 and Official 1, end of this section). Official 1 considers that recent direct experience of eruptive activity has increased local residents' risk awareness (supported by literature, e.g. Johnston et al. [1999]), but also that this awareness will motivate future willingness to evacuate. However, Section 4.2.1 showed that only nine months after $3^{\text {rd }}$ June, many local people appear again to normalise Fuego's behaviour. This suggests that in future eruptions local residents might not have the knowledge to distinguish normal eruptive activity from an eruptive crisis that requires them to evacuate. The official quoted in 2018 references local peoples' uncertainty in the face of volcanic activity ("What shall we do?") and presents this as an undesirable situation illustrating failure of the self-evacuation policy. This may be true, but it does not follow that the failure is due to local uncertainty. One must ask why local people don't have access to information about Fuego. Escobar-Wolf [2013] showed that many local people (66 \% of respondents in 2010, 101 people) considered themselves insufficiently informed of Fuego, agreeing that "you don't know when the volcano will become dangerous, and you need someone else with more knowledge to tell you when you should evacuate". Aside from a distinction between arena and ceniza, local people in 2019 were similarly uncertain, despite their recent experiences of June and November 2018. For example, the Ceilán resident who described pyroclastic flows in Section 4.1.2 was a member of the community COLRED, but had never seen pyroclastic flows before $3^{\text {rd }}$ June. This resident may not feel confident to advise others in the community about appropriate action to take - which for authorities would be evacuation. While knowledge gained by direct experience of natural hazards is important, combining such knowledge with training and access to scientific information is vital to developing local ability to cope with persistent eruptive activity and facility in decision-making regarding evacuation [Few et al. 2017; Mei et al. 2013].

The self-evacuation policy at Fuego also assumes availability of resources that expedite evacuation. Official 4 gives the example of escaping a house on fire to promote self-reliance - but one should wait for the arrival of firefighters, confident that their knowledge of the hazard and resources to quell the flames are greater than those of the person at risk, who holds no official responsibility for dealing with the fire. Similarly, while the efforts of CONRED to improve local knowledge of volcanic hazards and encourage resilience through planning and community co-operation are appropriate, we argue these efforts should be in support of, and not in place of, their own greater capacity and official responsibility.

Authors such as Haynes et al. [2008] have shown that local residents face significant barriers responding to volcanic activity that are deeply connected to the root causes of risk. Better evacuation systems and methods of communication may serve to improve this. However, these improvements should be primarily the responsibility of authorities, who have more resources available than local residents to achieve this.

Our interpretations of the self-evacuation policy's assumptions about knowledge and resources are supported by analysis of a CONRED infographic promoting self-evacuation (Figure 5). First, Step 1 assumes that every family can create a Family Response Plan, which requires internet access, literacy (both written and computational), and value judgements of priorities that themselves require knowledge. Many locals around Fuego lack some or all of these requirements and would not be able to create such a plan. Steps 2-3 assume that locals will (a) be able to access information through media such as radio; (b) be able to interpret the information received and incorporate it into their decision-making. However, there have been several major eruptions of Fuego in which communication pathways were damaged, including $3^{\text {rd }}$ June 2018. Furthermore, the lack of a shared vocabulary between locals and officials at Fuego (e.g. locals do not have a specific word to describe pyroclastic flows - see Section 4.1.2) suggests that these groups do not speak the same language, and therefore interpretation of any received information will be difficult. Development of a shared vocabulary is critically important in effective risk mitigation at analogue volcanoes [Armijos et al. 2017]. It appears that a shared understanding of tolerable risk does not exist at Fuego. Moreover, whose responsibility is it that this information is (a) accessible to, and (b) interpretable by locals? It is certainly not that of locals themselves. Finally, Step 4 uses ambiguous language ("begin self-evacuation") that implicitly assumes both a willingness and ability to evacuate. At Fuego the ability to self-evacuate is not supported by evidence: for example, evacuation is greatly facilitated by access to vehicles, but most people do not have access to transport and would have to evacuate on foot. This is slow and dangerous and would be greatly complicated by factors such as an eruption at night or having to carry young children or elderly relatives.

The third assumption of the self-evacuation policy (as examined through Figure 5 and the quotations of Section 4.2.2) relates to direct experience of volcanic activity. If local residents experience a change in volcanic activity that represents increased volcanic risk, they will then decide to evacuate. This approach is comparable to the hazard-perception approach studied in Section 2, where individuals perceive changes in 


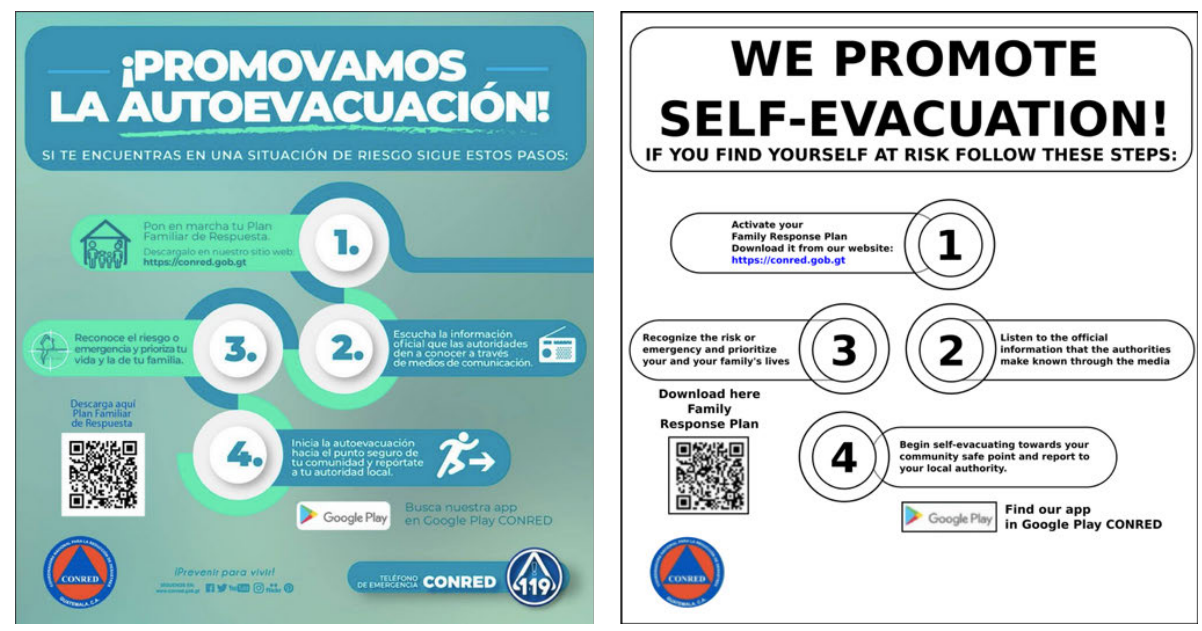

Figure 5: Infographic issued by CONRED promoting self-evacuation [left]; English translation [right].

their environments and make adjustments to minimize loss. Supported by more recent literature as well as this study's findings, we suggest this approach has certain flaws. We found that local residents describe their direct experiences of previous eruptive activity in a manner that shows that what they see is different from what officials see (Figure 3). Differences in how locals and officials see eruptive activity at Fuego may be through a difference in recognition of activity as an eruption or not (Section 4.1.1), or by comparison of an eruption to a previous, larger eruption (Section 4.1.2). Even if locals and authorities recognize the same eruptive activity, it is uncertain how influential this experience is in locals' decision to evacuate. In 2019, some locals stated that in a future eruptive crisis they would self-evacuate when they considered volcanic risk "high enough". This initially suggests that self-evacuation is a viable policy. However, when asked to describe a specific situation that would require them to evacuate, locals could not do so (with the exception of arena/ceniza). Locals' lack of a definite threshold for volcanic risk tolerance has previously been observed both at Fuego [León-Ramírez Carné 2012] and at analogous volcanoes like Mt Merapi [Mei et al. 2013]. At Mt Merapi, locals who were less familiar with official disaster risk reduction strategies were more reluctant to comply with evacuation orders, and several from under-educated areas were tragically killed in 2010 [Mei et al. 2013]. At Fuego, a further complication regarding direct experience of activity and its influence on self-evacuation occurs with the difference between communities on the east and west flanks that has until now not been acknowledged. In multiple studies of evacuation from natural hazards, the only two significant predictors of preparedness to act were (i) severity of previous direct experience of hazards, and (ii) trust and communication with outside stakeholders [Wachinger et al. 2013]. These predictors are also the two most explicit differences between eastern and western communities at Fuego (through, respectively, experiences of $20^{\text {th }}$-century eruptions and links with INSIVUMEH/CONRED). Therefore, a future eruption of Fuego may have very different outcomes between communities that are only a few kilometres apart, just as in 2018 we witnessed the different fates of San Miguel Los Lotes and La Reunión. By assuming that local residents will recognize eruptive activity at Fuego in the same way as officials do, the selfevacuation policy may have critical implications: if a community's knowledge and preparation are overestimated, they may be expected to organize an evacuation that they cannot achieve. Older residents referenced fall of arena as indication to evacuate (Section 4.1.2). However, the fall of arena would suggest the eruption had already reached a critical stage associated with hazards that may inhibit evacuation (e.g. through descent of pyroclastic flows and/or lahars preventing escape by road). We conclude that this judgement among older people means they would decide to evacuate only when it is too late to do so.

Other than the three main assumptions implicit in the self-evacuation policy, other factors such as communication may hinder the success of self-evacuation in future eruptive crisis. For example, local residents in 2019 stated they would rely on advice from INSIVUMEH or CONRED, consistent with results from Escobar-Wolf [2013]. As seen on many previous occasions at Fuego, this advice is either slow to arrive or does not come. From these findings we conclude that there are many deterrents to a community successfully organizing its self-evacuation from Fuego.

The self-evacuation policy has merit in avoiding bringing more people into an area of high risk. In many environments threatened by persistent volcanic activity, repeated temporary evacuations can be successful, given good trust between locals and authorities and security of domestic resources that encourages co-operative or proactive evacuation by locals [Andreastuti et al. 2019; Armijos et al. 2017; Few et al. 2017]. However, the results of this study show that in 2019 these conditions were not in place at Fuego. 
Trust between locals and authorities is heterogeneous around the volcano, suggesting that in the event of a future eruptive crisis, both knowledge of hazards and a willingness to evacuate may be inconsistent between communities, as seen at Mt Merapi [Donovan et al. 2012; Mei et al. 2013]. Furthermore, the three assumptions implicit in self-evacuation policy-knowledge, resources, and experience-are not validated by our findings from interviews with local residents. Selfevacuation dictates that in the event of crisis, information and advice will issue from INSIVUMEH and CONRED, but local authorities must make the decision to evacuate themselves. However, a lack of shared vocabulary between locals and authorities (e.g. in the term "pyroclastic flow") suggests that the information INSIVUMEH and/or CONRED share during heightened activity may not be understood in the manner intended. Furthermore, in a future eruption conditions may prevail that prevent local people from resources that give them further information of volcanic activity, similar to what occurred on $3^{\text {rd }}$ June 2018 (e.g. low visibility due to cloud, poor phone signal). The lack of such information may discourage locals from leaving in the spirit of prevention encouraged by self-evacuation. In addition, people in rural communities face significant logistical barriers to evacuating that those in La Reunión do not have (e.g. difficulty in reuniting families (men generally work in the field, women at home); lack of transporting vehicles). During the last days of fieldwork in 2019, an official from INSIVUMEH expressed some final thoughts on the hopes and challenges that lie ahead:

Interviewer: And what do you think of ... have there been changes since the tragedy in June? If another eruption happens now, what are the things that have changed most?

Official 1: Well, it's that the people know that they are living in a volcanic area. That they cannot confide in it as before, "Ah, it's having another eruption". Another eruption comes - "Ah, it's only making a noise!". Now, I think that they ... they are the best volcanologists now. They can distinguish now between pyroclastic flows, lava flows, everything. Now they know perfectly.

\section{Interviewer: The lived experience.}

Official 1: Yes. That's it, they know now what can happen and where they mustn't be. Because it was all ... well, I'm aware that also CONRED people have been working around the volcano for some time. But the people weren't interested, they didn't go to the meetings, no. But now I think that... it's the opportunity for CONRED to work with the communities. And with us too ... raising consciousness in people while they can.

\section{Conclusions}

In recent decades, volcanological research has increasingly recognized the importance of including local knowledge to obtain a holistic understanding of volcanic risk. Meanwhile, research on evacuation from natural hazards shows that trust in authorities and direct previous experience are factors that strongly influence the decision to evacuate. Our research contributes to the debate of direct experience of eruptive activity and evacuation through an in-depth case study conducted over two years at the active Volcán de Fuego in Guatemala. Our study confirmed findings in previous literature that eruptive activity is experienced differently by different people. At Volcán de Fuego, local residents' experiences of previous eruptive activity differ significantly from authorities' experiences over the same period. Furthermore, experiences of local residents were not homogenous but diverged significantly between residents of communities on Fuego's western flanks and residents of communities further east. This study has revealed a previously unreported difference between residents Fuego's west and east flanks in terms of (1) direct experience of the eruptions of 1966 and 1974, and (2) trust and communication with INSIVUMEH/CONRED. These findings suggest that volcanic risk may be even more localized than previously considered, and that experiences of previous eruptions can influence response to activity decades after the initial event. The difference between Fuego's west and east flanks highlights the importance of responsibility and choice in response to eruptive activity. Local people are highly restricted by their responsibilities to their land and livelihoods, they may hold a strong attachment to their home, and the choices that they make are influenced by this. Previous experiences of livelihood devastation in the $20^{\text {th }}$ century appears to have influenced, and continues to influence, the choices of local people on the west flanks of Fuego in a way it has not further east. The different relationships between INSIVUMEH and CONRED with communities on different sides of the volcano provides them with different information and different sources of trust that in turn shape an individual's risk at Fuego. As in analogous environments such as Tungurahua, volcanic risk at Fuego is not static but variable with time and with location. An individual living in Ceilán and volunteering in its COLRED lives with a completely different risk from that of his elderly isolated aunt whom he visits in Panimaché Uno.

Our assessment of how local residents experience eruptive activity and trust in authorities allow us to consider (1) how these two factors influence their decision to evacuate from eruptive crisis; and (2) how CONRED's current policy of self-evacuation should be viewed in light of the findings. Differences in how people experience eruptions may impact the success of future evacuation efforts because different people disagree in the threshold of volcanic risk that can be toler- 
ated before a decision to evacuate is made. At other volcanoes, acceptance of both local and official experiences has created effective adaptive volcanic risk mitigation strategies. We argue that at Fuego, local residents' direct experiences of previous activity are an under-used resource; acknowledging these experiences by including them in training and policy may empower locals and encourage their collaboration with INSIVUMEH and CONRED in strengthening existing risk mitigation strategies.

The current policy of self-evacuation encourages community empowerment through a transfer of responsibility for deciding to evacuate to local communities. It also has the additional benefit of avoiding bringing more people into a high-risk zone. Nevertheless, our study showed that self-evacuation contains implicit assumptions about local residents' knowledge, resources, and experiences. These assumptions were not confirmed by interviews with local residents. Local residents are knowledgeable of Fuego's activity but lack knowledge of specific hazards such as pyroclastic flows to make the decision to evacuate without difficulty. Other factors as lack of resources and security fears further complicate the decision to evacuate.

Fuego remains a highly active volcano, and the populations close to its summit continue to increase. If risk mitigation policy fails to recognize the different ways of experiencing eruptive activity, or ignores the social and economic pressures that may disincentivize locals from making the decision to evacuate, it is uncertain whether the rich knowledge of hazards and qualitative assessments of risk that local residents include in their experiences of Fuego's activity may translate into them taking sufficient protective measures to preserve life in the case of a future explosive eruption.

\section{Acknowledgements}

We would like to give thanks to all people at Volcán de Fuego who were willing to participate in this investigation. Funding for this project was provided by NERC (grant number NE/L002434/1). AKN and IMW would like to acknowledge the assistance of NERC Urgency Grant NE/S011498/1.

\section{Author COnTributions}

AN designed the study, led fieldwork, analysed transcripts, translated interview data, and led drafting of the manuscript. TA guided the study design throughout fieldwork and contributed to the development of the manuscript. WC and EB assisted in data collection. MW assisted with fieldwork and contributed to writing. All authors have made a substantial and intellectual contribution to the work and approved it for publication.

\section{Data AVAILABility}

Questionnaire design (in English) is included as Supplementary Material alongside the online version of this article. Research design and questionnaire design (in Spanish) available on request from the corresponding author.

\section{COPYRIGHT NOTICE}

(C) The Author(s) 2020. This article is distributed under the terms of the Creative Commons Attribution 4.0 International License, which permits unrestricted use, distribution, and reproduction in any medium, provided you give appropriate credit to the original author(s) and the source, provide a link to the Creative Commons license, and indicate if changes were made.

\section{REFERENCES}

Albino, F., J. Biggs, R. Escobar-Wolf, A. Naismith, M. Watson, J. Phillips, and G. C. Marroquin (2020). "Using TanDEM-X to measure pyroclastic flow source location, thickness and volume: Application to the 3rd June 2018 eruption of Fuego volcano, Guatemala". Journal of Volcanology and Geothermal Research 406, p. 107063. Dor: 10.1016/j . jvolgeores.2020.107063.

Andreastuti, S., E. Paripurno, H. Gunawan, A. Budianto, D. Syahbana, and J. Pallister (2019). "Character of community response to volcanic crises at Sinabung and Kelud volcanoes". Journal of Volcanology and Geothermal Research 382, pp. 298-310. DoI: 10.1016/j . jvolgeores. 2017.01.022.

Armijos, M. T. and R. Few (2015). "Living with volcanic risk: Vulnerability, knowledge and adaptation in the slopes of Tungurahua, Ecuador". DEV Report and Policy Papers Series. School of International Development, University of East Anglia, Norwich, UK.

Armijos, M. T., J. Phillips, E. Wilkinson, J. Barclay, A. Hicks, P. Palacios, P. Mothes, and J. Stone (2017). "Adapting to changes in volcanic behaviour: Formal and informal interactions for enhanced risk management at Tungurahua Volcano, Ecuador". Global Environmental Change 45, pp. 217-226. DoI: $10.1016 / j$. gloenvcha.2017.06.002.

Associated Press (2018). "Guatemala ups number of missing to 332 in volcano eruption". Associated Press News. [online].

Atkinson, R. and J. Flint (2004). "Snowball sampling". The SAGE encyclopedia of social science research methods. Ed. by M. S. Lewis-Beck, A. Bryman, and T. Futing Liao. Thousand Oaks, CA: Sage Publications. DoI: 10.4135/9781412950589.n931.

Bankoff, G. (2007). "Living with risk; coping with disasters". Education about Asia 12.2, pp. 26-29. 
Barclay, J., R. Few, M. T. Armijos, J. C. Phillips, D. M. Pyle, A. Hicks, S. K. Brown, and R. E. A. Robertson (2019). "Livelihoods, Wellbeing and the Risk to Life During Volcanic Eruptions". Frontiers in Earth Science 7. DoI: 10.3389 /feart. 2019.00205.

Barclay, J., K. Haynes, T. Mitchell, C. Solana, R. Teeuw, A. Darnell, H. S. Crosweller, P. Cole, D. Pyle, C. Lowe, C. Fearnley, and I. Kelman (2008). "Framing volcanic risk communication within disaster risk reduction: finding ways for the social and physical sciences to work together". Geological Society, London, Special Publications 305.1, pp. 163-177. Dor: 10.1144/sp305. 14.

Bird, D. K. (2009). "The use of questionnaires for acquiring information on public perception of natural hazards and risk mitigation - a review of current knowledge and practice". Natural Hazards and Earth System Sciences 9.4, pp. 1307-1325. DoI: $10.5194 /$ nhess-9-1307-2009.

Blaikie, P., T. Cannon, I. Davis, and B. Wisner (2014). At risk: natural hazards, people's vulnerability and disasters. Routledge.

Bonis, S. and O. Salazar (1973). "The 1971 and 1973 eruptions of Volcán Fuego, Guatemala, and some socio-economic considerations for the volcanologist". Bulletin Volcanologique 37.3, pp. 394-400. DOI: 10 . $1007 / \mathrm{bf} 02597636$.

Cashman, K. V. and S. J. Cronin (2008). "Welcoming a monster to the world: Myths, oral tradition, and modern societal response to volcanic disasters". Journal of Volcanology and Geothermal Research 176.3, pp. 407-418. Dor: $10.1016 / \mathrm{j}$. jvolgeores. 2008 . 01 . $\odot 40$.

Christie, R., O. Cooke, and J. Gottsmann (2015). "Fearing the knock on the door: critical security studies insights into limited cooperation with disaster management regimes". Journal of Applied Volcanology 4.1. DoI: $10.1186 / \mathrm{s} 13617-015-0037-7$.

Cresswell, J. W. (2014). Research Design: Qualitative, Quantitative, and Mixed Methods Approaches.

Cronin, S. J. and K. V. Cashman (2016). "Volcanic oral traditions in hazard assessment and mitigation". Living Under the Shadow. Ed. by J. Grattan and R. Torrence. Routledge, pp. 185-212.

Cronin, S. J., M. G. Petterson, P. W. Taylor, and R. Biliki (2004). "Maximising Multi-Stakeholder Participation in Government and Community Volcanic Hazard Management Programs; A Case Study from Savo, Solomon Islands". Natural Hazards 33.1, pp. 105136. DoI: $10.1023 / \mathrm{b}:$ nhaz .0000035021.09838.27.

Dibben, C. J. (1999). "Looking beyond eruptions for an explanation of volcanic disasters: vulnerability in volcanic environments". PhD thesis. University of Bedfordshire, UK.

- (2008). "Leaving the city for the suburbs-The dominance of 'ordinary' decision making over volcanic risk perception in the production of volcanic risk on Mt Etna, Sicily". Journal of Volcanology and Geother- mal Research 172.3-4, pp. 288-299. DoI: $10.1016 / \mathrm{j}$. jvolgeores. 2007.12.014.

Donovan, A., J. R. Eiser, and R. S. J. Sparks (2014). "Scientists' views about lay perceptions of volcanic hazard and risk". Journal of Applied Volcanology 3.1. Dor: $10.1186 / \mathrm{s} 13617-014-0015-5$.

Donovan, K., A. Suryanto, and P. Utami (2012). "Mapping cultural vulnerability in volcanic regions: The practical application of social volcanology at $\mathrm{Mt}$ Merapi, Indonesia". Environmental Hazards 11.4, pp. 303-323. DoI: 10.1080/17477891.2012.689252.

Dove, M. R. (2008). "Perception of volcanic eruption as agent of change on Merapi volcano, Central Java". Journal of Volcanology and Geothermal Research 172.34, pp. 329-337. DoI: $10.1016 / j$. jvolgeores . 2007. 12.037.

Escobar-Wolf, R. P. (2013). "Volcanic processes and human exposure as elements to build a risk model for Volcan de Fuego, Guatemala". PhD thesis. Michigan Technological University, US.

Ferres, D. and R. Escobar-Wolf (2018). Informe Técnico: Volcán de Fuego. Acción Contra El Hambre y Cooperación Española. Tech. rep. Acción Contra el Hambre (Guatemala).

Few, R., M. T. Armijos, and J. Barclay (2017). "Living with Volcan Tungurahua: The dynamics of vulnerability during prolonged volcanic activity". Geoforum 80, pp. 72-81. DoI: $10.1016 / j$.geoforum . 2017.01 . 006.

Flyvbjerg, B. (2006). "Five Misunderstandings About Case-Study Research". Qualitative Inquiry 12.2, pp. 219-245. Dor: 10.1177/1077800405284363.

Gaillard, J.-C. (2008). "Alternative paradigms of volcanic risk perception: The case of Mt. Pinatubo in the Philippines". Journal of Volcanology and Geothermal Research 172.3-4, pp. 315-328. Dor: $10.1016 / j$. jvolgeores.2007.12.036.

Gaillard, J.-C. and J. Mercer (2013). "From knowledge to action". Progress in Human Geography 37.1, pp. 93114. DOI: $10.1177 / 0309132512446717$.

Graves, K. L. (2007). "Risk Perception of Natural Hazards in the Volcanic Regions of Ecuador and Guatemala”. MA thesis. Michigan Technological University, US.

Hayes, J. (2018). "Stories and Standards: The Impact of Professional Social Practices on Safety Decision Making". Beyond Safety Training: Embedding Safety in Professional Skills. Ed. by C. Bieder, C. Gilbert, and B. J. anf Hervé Laroche. Springer, Cham, pp. 73-83.

Haynes, K., J. Barclay, and N. Pidgeon (2008). "Whose reality counts? Factors affecting the perception of volcanic risk". Journal of Volcanology and Geothermal Research 172.3-4, pp. 259-272. Dor: $10.1016 /$ j. jvolgeores.2007.12.012.

Hewitt, K. (1983). "The Idea of Calamity in a Technocratic Age". Interpretations of Calamity. Ed. by K. Hewitt. Allen and Unwin Inc. 
Hicks, A., M. T. Armijos, J. Barclay, J. Stone, R. Robertson, and G. P. Cortés (2017). "Risk communication films: Process, product and potential for improving preparedness and behaviour change". International Journal of Disaster Risk Reduction 23, pp. 138-151. Dor: 10.1016/j.ijdrr.2017.04.015.

Hicks, A., J. Barclay, P. Simmons, and S. Loughlin (2014). "An interdisciplinary approach to volcanic risk reduction under conditions of uncertainty: a case study of Tristan da Cunha". Natural Hazards and Earth System Sciences 14.7, pp. 1871-1887. DOI: 10 . 5194/nhess-14-1871-2014.

Hoepfl, M. C. (1997). “Choosing Qualitative Research: A Primer for Technology Education Researchers". Journal of Technology Education 9.1. Dor: 10.21061/ jte.v9i1.a.4.

Jóhannesdóttir, G. and G. Gísladóttir (2010). "People living under threat of volcanic hazard in southern Iceland: vulnerability and risk perception". Natural Hazards and Earth System Sciences 10.2, pp. 407-420. Dor: $10.5194 /$ nhess-10-407-2010.

Johnston, D. M., M. S. B. C.-D. Lai, B. F. Houghton, and D. Paton (1999). "Volcanic hazard perceptions: comparative shifts in knowledge and risk". Disaster Prevention and Management: An International Journal 8.2, pp. 118-126. DoI: 10.1108/09653569910266166.

Lane, L. R., G. A. Tobin, and L. M. Whiteford (2003). "Volcanic hazard or economic destitution: hard choices in Banños, Ecuador". Environmental Hazards 5.1, pp. 23-34. Dor: 10.1016/j . hazards . 2004.01.001.

León-Ramírez Carné, A. X. L. (2012). “Evaluación de la vulnerabilidad asociada a la amenaza del Volcán de Fuego en la aldea Panimaché”. MA thesis. Universidad de San Carlos de Guatemala (USAC), Guatemala.

Lyons, J. J., G. P. Waite, W. I. Rose, and G. Chigna (2010). "Patterns in open vent, strombolian behavior at Fuego volcano, Guatemala, 2005-2007". Bulletin of Volcanology 72.1, pp. 1-15. DOI: 10.1007 /s00445$009-0305-7$.

Mei, E. T. W., F. Lavigne, A. Picquout, E. de Bélizal, D. Brunstein, D. Grancher, J. Sartohadi, N. Cholik, and C. Vidal (2013). "Lessons learned from the 2010 evacuations at Merapi volcano". Journal of Volcanology and Geothermal Research 261, pp. 348-365. DoI: 10.1016/j. jvolgeores. 2013.03.010.

Naismith, A. K. (2020). "Todo se oscureció: uniting remote sensing observations and human experiences to understand recent eruptive activity of Volcán de Fuego, Guatemala”. PhD thesis. University of Bristol, UK.

Naismith, A. K., I. M. Watson, R. Escobar-Wolf, G. Chigna, H. Thomas, D. Coppola, and C. Chun (2019). "Eruption frequency patterns through time for the current (1999-2018) activity cycle at Volcán de Fuego derived from remote sensing data: Evidence for an accelerating cycle of explosive paroxysms and potential implications of eruptive activity". Journal of Volcanology and Geothermal Research 371, pp. 206-219. DoI: $10.1016 / \mathrm{j}$. jvolgeores. 2019.01.001.
Noticias ONU (2018). "La erupción del volcán de Fuego afecta a 1,7 millones de personas en Guatemala". Noticias ONU. [online, in Spanish].

Palinkas, L. A., S. M. Horwitz, C. A. Green, J. P. Wisdom, N. Duan, and K. Hoagwood (2015). "Purposeful Sampling for Qualitative Data Collection and Analysis in Mixed Method Implementation Research". Administration and Policy in Mental Health and Mental Health Services Research 42.5, pp. 533-544. DoI: 10 . $1007 / \mathrm{s} 10488-013-0528-\mathrm{y}$.

Pistrang, N. and C. Barker (2012). "Varieties of qualitative research: A pragmatic approach to selecting methods." APA handbook of research methods in psychology, Vol 2: Research designs: Quantitative, qualitative, neuropsychological, and biological. American Psychological Association, pp. 5-18. DoI: 10.1037/ 13620-001.

Ritchie, J. (2003). "The applications of qualitative methods to social research". Qualitative research practice: A guide for social science students and researchers. Ed. by J. Ritchie and J. Lewis. SAGE Publications Ltd, pp. 24-46.

Rose, W. I., S. Self, P. J. Murrow, C. Bonadonna, A. J. Durant, and G. G. J. Ernst (2008). "Nature and significance of small volume fall deposits at composite volcanoes: Insights from the October 14, 1974 Fuego eruption, Guatemala". Bulletin of Volcanology 70.9, pp. 1043-1067. DoI: 10.1007/s00445-007-0187-5.

RT (2018). "VIDEO: Momento exacto de la erupción del Volcán de Fuego en Guatemala". RT. [online, in Spanish].

Stone, J., J. Barclay, P. Simmons, P. D. Cole, S. C. Loughlin, P. Ramón, and P. Mothes (2014). "Risk reduction through community-based monitoring: the vigias of Tungurahua, Ecuador". Journal of Applied Volcanology 3.1. DOI: $10.1186 / \mathrm{s} 13617-014-0011-9$.

Tobar, J. E. (2018). "Las alertas ignoradas por Conred y la cifra dudosa de desaparecidos". Nómada. [online, in Spanish].

Van Loon, A. F., I. Lester-Moseley, M. Rohse, P. Jones, and R. Day (2020). "Creative practice as a potential tool to build drought and flood resilience in the Global South". Dor: 10.5194/gc-2020-11.

van Manen, S. M. (2014). "Hazard and risk perception at Turrialba volcano (Costa Rica);implications for disaster risk management". Applied Geography 50, pp. 63-73. Dor: 10.1016/j . apgeog.2014.02.004.

Wachinger, G., O. Renn, C. Begg, and C. Kuhlicke (2013). "The Risk Perception Paradox-Implications for Governance and Communication of Natural Hazards". Risk Analysis 33.6, pp. 1049-1065. DoI: 10 . 1111/j.1539-6924.2012.01942.x.

White, G. (1942). "Human adjustment to floods: A geographical approach to the flood problem in the United States". PhD thesis. Department of Geography, University of Chicago, USA. 